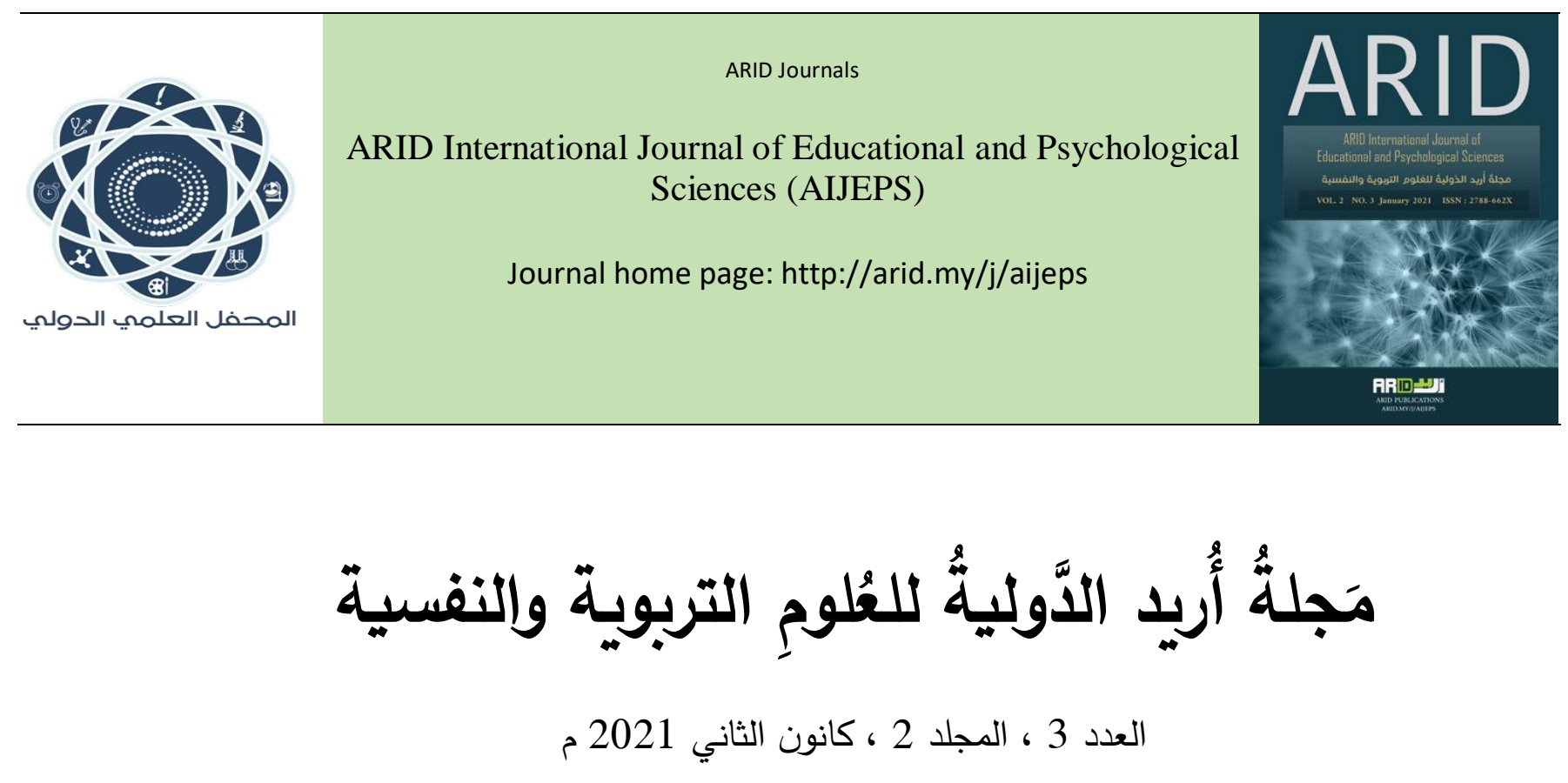

\title{
Creative writing expression skills and their availability among linguistically gifted middle school students
}

Abdel Razek Mokhtar Mahmoud

\author{
مهار ات التعبير الكتابي الإبداعي ومدى توافرها لدى تلاميذ المرحلة الإعدادية الموهوبين لغويًا$$
\text { عبدالرازق مختار محمود }
$$$$
\text { أستاذ المناهج وطرق التدريس- كلية التربية- جامعة أسيوطـ مصر }
$$

Razic2005@gmail.com

Arid.my/0001-2264

https://doi.org/10.36772/arid.aijeps.2021.231 


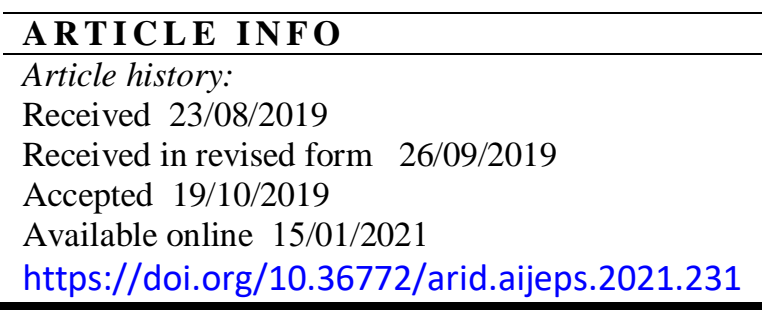

\begin{abstract}
The aim of the current research is to determine the appropriate creative writing expression skills for linguistically gifted middle school students (first grade of middle school) and know their availability. To achieve the goal of the research, the researchers followed each of the descriptive approach when reviewing previous studies and preparing the theoretical framework, and the experimental one-group approach when applying Research tools, and the search group consisted of linguistically gifted first-grade pupils, and their number reached (37) male and female students. They were selected according to the linguistically gifted student identification and detection tools identified in the current research. The two researchers prepared a list of the characteristics of linguistically gifted pupils (cognitive - emotional - linguistic), numbering (56), and the other with the skills of creative writing expression appropriate for the first grade linguistically gifted preparatory students, which number (14) skills, and tested the skills of creative writing for the first graders of the gifted middle school. Linguistically. By applying the prepared test, the research found the weakness of the creative writing skills of first grade, linguistically gifted middle school pupils at levels of (fluency - flexibility - originality).

In light of the results of the current research, it is recommended to conduct more studies that are concerned with creative written expression and develop their skills among learners in general and the talented linguistically in particular, and employ modern strategies in teaching expression, and raise the efficiency of teachers by holding periodic training courses for them on how to use these Strategies, attention to areas of creative writing expression that are of interest to students and related to their lives, and present them to them in appropriate ways. Arabic language books include some topics of creative writing, and other suggested recommendations and research.
\end{abstract}




\section{ملخص البحث:}

هدف البحث الحالي إلى تحديد مهار ات التعبير الكتابي الإبداعي المناسبة لتلاميذ المرحلة الإعدادية (الصف الأول الإعدادي) الموهوبين

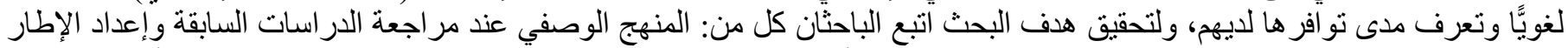

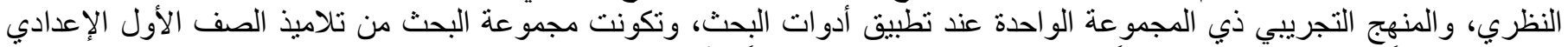

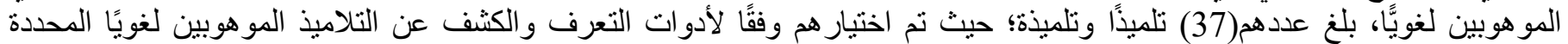

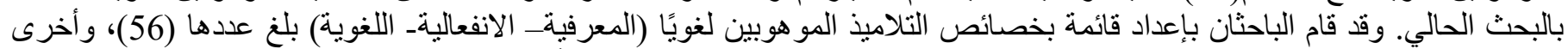

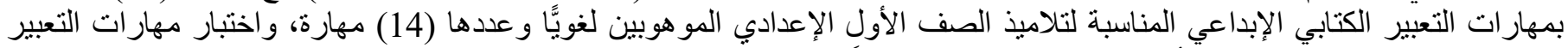

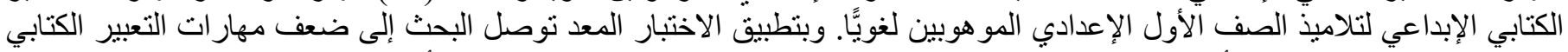

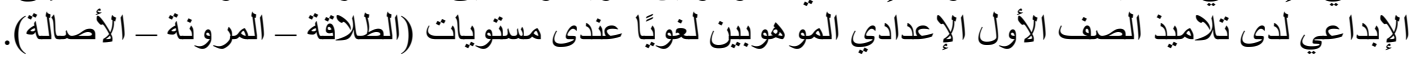

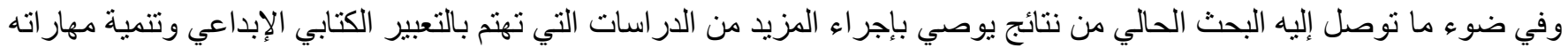

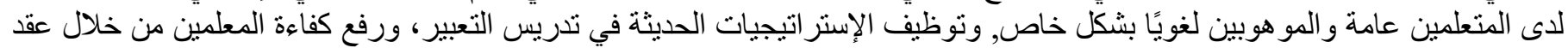

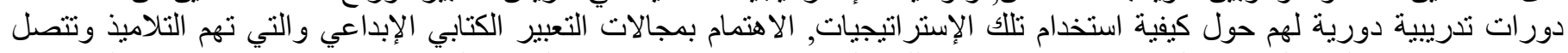
بحياتهم، وتقديمها لهم بالطر ائق المناسبة, تضمين كتب اللغة العربية بعض موضوعات التعبير الكتابي الإبداعي, وغير ها من التوصيات و البحوث المقترحة.

الكلمات المفتاحية: التعبير الكتابي الإبداعي ـ المو هوبون لغويًا تناميذ المرحلة الإعدادية. 
خلق الله سبحانه وتعالىــ الناس وميز هم عن بعضـهم بعضًا بملكات معينـة، يُطلق عليها "المو هبـة الفطريـة", و التي إذا مـا تم اكتشافها في وقت مبكر, وتناولها المختصون وتعهدو ها بالر عاية فإنها تُصقل ويكون لها شأن كبير, أمـا إذا لم يتم الكثف عنها و الاهتمام بها, فإنها تفنى ويصبح صاحبها كغيره من أقرانه, ويفقد المجتمع تلك المنحة الإلهية التي قُمت له ولم يُحسن استغلالها. و لا يخفى على أحد أن مجالات المو هبـة و الإبداع عند المتعلمين تتطلب جهودًا هادفةً ومنظمـةً من قِبـل التربويين, للعمل على استنهاض القدرات الكامنة لدى المو هوبين، وتحويلها إلى أداء مميز وذي فائدة للمجتمع, وفق مجال النبوغ الذي يتميز فيه الموهوب, علميَّا كان أو أدبيَّا. و المو هبة اللغوية من أهم مجالات الموهبة؛ حيث يمتاز المو هوب لغويًا بسمات وخصائص تميزه عن غيره من المو هوبين فى المجالات الأخرى، كما أنَ لله حاجـات ومطالب ينبخى الوفاء بها, مـا يبرز الحاجـة إلى الكثف عن الموهوبين لغويًا وتعرفهم، وتحديد مستوى أدائهم اللغوى؛ لتتمية القدرات المتعددة لديهم (قاسم، 2005، 11) 1. و يعد المتعلمون المو هوبون على اختـلاف مواهبهم أهم مصدر للثروة البشرية في أي مجتمع مـن المجتمعات، فالمطلب الأسـاس للّحاق بركب التقدم هـو رعاية المو هو بين و المبتكرين القادرين على إيجاد الحلول لكثير من المشكلات التي تهدد الفـرد و المجتمع، وفئة المو هو بين فئة ذهبية وثروة قومية؛ حيث يكون من بين هؤ لاء المو هوبين صفوة العلماء والمبتكرين (الثـربيني وصـادق، 2002، 17). فيمتاز التلميذ المو هوب لغويًا بقدرة غير عادية على حفظ المعلومات واختز انها، وبالتطور اللغوي، وكذلك بقدرة لفظية من مستوى عـالٍ، واستخدام التعبيرات و القياسـات المجردة، والتسـاؤل الدائم, و التفكير المتشـع، والقدرة على التحليل و الاستدلال، وربط الخبرات السابقة باللاحقة، و أنه يستمتع بقر اءة القصص وكتابة القصائد الشعرية وتحرير ها (الخطيب، 2003، 251). و عند الحديث عن الإبداع و الأداء اللغوي الإبداعي, يلحظ أن للغة العربية طبيعتها المتفردة؛ حيث تجد للفظ الواحد أكثر من معنى، وللمعنى أكثر من لفظ، ولكي يكون العمل الإبداعي أصيلًا في ثوبه، لا بد أن تكون الأفكار المنقولة في النّّّ المعروض بعيدًا عن المألوف بطريقة مبتكرة توشحها الزّخارف اللّغويّة المستوحاة من البلاغـة العربيّة و الكتابـة بطبيعتها عملية عقليّة عاليـة التّعقيد تتضمن عمليات متتوعة كتوليد الفكر ، وصياغتها على هيئة مسودة، والمر اجعة، والتّقيح، والنّشر رو هذا ما أثشارت إلبه در اسات كل من: محمود(2007) و التي هدفت إلى تتمية مهار ات الإبداع اللغوي من خلال برنامج تدريبي مقترح في إكساب معلمي اللغة العربيـة مهار ات استخدام الذكاءات المتعددة في تدريسهح, ودر اسـة محمود وآخرين(2016) و التي استهدفت تنميـة مهار ات الإبداع اللغوي لدى طالبات المرحلة الثانوية باستخدام نمةذج تدريسي في الأدب قائم على نظريـة التعلم المستند إلى الدماغ, كماهدفت در اسـة فرج(2020)

APA Style of the Publication Manual of the American Psychological تم اتباع نظام توثيق جمعية علم النفس الأمريكية 


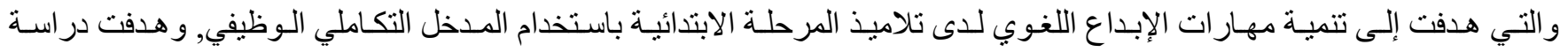
محمد(2020) و التي هدفت إلى تتمية مهار ات الإبداع اللغوي لاى تلاميذ الصف الأول الإعدادي باستخدام إستر اتيجية سكامبر. ويعد التعبير الكتابي الإبداعي من أرقى أنواع التعبير و أعظمها إيقاعًا؛ لأنه يحقق المتعة النفسية للفرد، وينمي مواهبه, ويصقل شخصيته من خلال كتاباته، والتي تظهر فيها الجدة والأصالة والعمق في التفكير, وتكمن أهمية التعبير الإبداعي في أنه القالب الذي يصب فيه الإنسان أفكاره ويعبر من خلاله عن أحاسيسه ومشاعره وآرائه (أبو لبن، 2016، 267). ويعرف عطيـة وحسافظ (2006، 7) التعبيـر الكتـابي الإبـداعي بأنـه تعبير الفرد عن مشـاعره وأحاسيسهـه وعواطفه و أفكـاره و معتقداته و آرائه في لغة جميلة في الأسلوب، واضحة في المعاني، وأصيلة في الأفكار ، وشيقة في العرض؛ بما يحقق المشاركة الوجدانية و القبول لدى المتلقي. فالتعبير الكتابي الإبداعي يتيح للتلاميذ التعبير عن أفكار هم ومشاعر هم وأحاسيسهم بشكل أكثر وضوحًا وجمالً؛ ليجعل كتاباتهم متسلسلة البنيان, معبرة عن المضمون بدون لبس في تفاصيل الموضوع، كما أنها تزيد من نشاط التلاميذ الكتابي وتحرر هم من القيود. وتظهر أهمية التعبير الإبداعي على الصعيد المدرسي في نمو شخصيات التلاميذ وتكاملها، فالتلاميذ في المرحلة المتوسطة و الإعدادية خاصة أحوج ما يكون للنعبير عن عواطفهم ومشاعر هم، حيث يسعى المعلم من خلال التعبير الإبداعي إلى تتمية قدرة التلاميذ على التخيل ومسـاعدتهم على الابتكار والإبـداع(عباس، 2004، 92-93). ومـن الدراسـات التي أكدت أهميـة التعبير التعبير الإبداعي دراسة كل: محمد(2014) و التي هدفت إلى تتمية دهار ات الأداء اللغوي الإبداعي لدى تلاميذ المرحلة الإعدادية المو هوبين باستخدام برنامج قائم على تآلف الأشتات وبرنامج سكامبر, و أحمد(2017) التي استهدفت تتمية مهارات التعبير الكتابي الإبداعي في اللغـة العربيـة لدى التلاميذ المو هو بين بالمدرسة الإعدادية باستخدام إستر اتيجية قائمة على مدخل عمليات الكتابـة, وكذا الجبوري(2017) و التي هدفت إلى تنمية مهار ات التعبير الكتابي الإبداعي لدى طلاب المرحلة الثانويـة بجمهوريـة العراق باستخدام برنـامج مقترح في التذوق الأدبي, و عبد العـال(2018) إلى تنميـة مهار ات الكتابـة الإبداعيـة لدى تلاميذ الصف الثاني الإعدادي عن طريق استخدام إستر اتيجية التخيل الموجه.

وقد أوصت هذه البحوث و الدر اسات بالا هتمام بتناول مهارات التعبير الكتابي الإبداعي و العمل على تنميتها لدى المتعلمين؛ لما لذللك من أهمية في تقوية لغتهم وتتميتها, وتمكينهم من التعبير السليم عن خو اطر هم كتابةً, وتهيئتهم لمو اجهة مختلف المواقف الحياتية التي تتطلب فصـاحة اللسـان و القدرة على الارتجـال بإبداع؛ لذلك سعى البحث الحسالي إلى تحديد مهارات التعبير الكتابي الإبداعي المناسبة لتلاميذ المرحلة الإعدادية وتعرف مدى تو افر ها لايهم. 


\section{مشكلة البحث:}

\section{نبعت مشكلة البحث الحالي من خلال الشواهد التالية:}

ـ الاطلاع على نتائج الاراسات السابقة التي أكلت أهمية تنمية مهارات التعبير الكتابي بصفة عامة، ومهار ات التعبير الكتابي الإبداعي بصفة خاصة لدى المتعلمين، مثل: در اسة عبد الباري(2016) و التي هدفت إلى تتمية مهار ات التعبير الكتابي الإبداعي باستخدام برنامج قائم على الخرائط الذهنية، ودر اسة أحمد(2017) التي استهدفت تنمية مهارات التعبير الكتابي الإبداعي لدى التلاميذ الموهوبين بالمرحلة الإعدادية من خلال إستر اتيجية قائمة على مدخل عمليات الكتابة، ودراسة الجبوري(2017) والتي هدفت إلى تتمية مهارات التعبير الكتابي الإبداعي لدى طلاب المرحلة الثانوية من خلال برنامج مقترح. ـ استثارة الخبراء والمختصين في مجال تدريس اللغة العربية: فقد تمت استشـارة عدد من الخبراء والمختصين في مجال تدريس اللغـة العربية بصورة عامـة، وتدريس اللغـة العربيـة بالمرحلة الإعدادية للتلاميذ المو هو بين بصفة خاصة بلغ عددهم (13)، وقد أنشاروا إلى أهمية تتمية تلك المهار ات لدى المتعلمين. ـ نتائج الاراسة الكشفية: وفي محاولة للتأكد من مستوى التلاميذ المو هوبين لغويًا في مهارات التعبير الكتابي الإبداعي؛ قام الباحثان بتطبيق اختبار في بعض مهار ات التعبير الكتابي الإبداعي على مجموعة من تلاميذ الصف الأول الإعدادي الموهوبين لغويَّا بلغ عددهم (21) تلميذًا، وتضمن الاختبار ثلاث مهار ات رئيسة (الطلاقة، المرونـة، الأصسالة), و اشتمل على اثني عشر سؤالًا، وقد أظهرت نتائج الاختبار وجود ضعف في مهار ات التعبير الكتابي الإبداعي لدى التلاميذ؛ حيث أسفرت النتائج عن وجود ضـف لدى 76.2 \% من التلاميذ الموهوبين لغويَا في مهار ات الطلاقة في التعبير الكتابي, و66.7\% من التلاميذ المو هوبين لغويًا لديهم ضـف في مهارات المرونة في التعبير الكتابي, وكذلك 52.4 \% منهم لديهم ضعف في مهار ات الأصالة في التعبير الكتابي. مما سبق تحددت مشكلة البحث الحسالي في ضعف تلاميذ الصف الأول الإعدادي المو هوبين لغويَّا في بعض مهارات التعبير

$$
\text { الكتابي الإبداعي. }
$$

\section{مصطات البحث:}

ـ التعبير الكتابي الإبداعي: يعرف بأنه فن أدبي نثري، يترجم فيه الكاتب حقيقة إحساسه تجاه الأشياء من حوله، ويعكس فلسفة معينة في الفكر و المعتقد، من خـلال الكتابة في موضوع معين، يدور حول فكرة مـا، بأسلوب أدبي متميز، يكثف عن موهبة فنية في الكتابـة، وسيطرة و اضحة على اللغة، وينبئ بمستقبل ز اهر (حماد ونصار ، 2002، 27). 
ويعرف التعبير الكتابي الإبداعي إجرائيا بأنه مجموعة الأداءات التي تمكن تلاميذ الصف الأول الإعدادي المو هوبين لغويًا من التعبير عما بداخلهم من مشـاعر و أفكار تعبيرًا و اضحًا صحيحًا, باختيار الألفاظ المناسبة, مستخدمًا في ذلك مهار ات الإبداع الرئيسـة: الطلاقة, والمرونة, والأصالة, ويقاس بالدرجة التي يحصل عليها التلميذ على اختبار التعبير الكتابي الإبداعي المعد بالبحث الحالي. ـ الموهوب:

"هو المتعلم الذى يظهر أداءً متميزًا مقارنة مع المجموعة العمرية التى ينتمى إليها فى واحدة أو أكثر من الأبعاد التالية: القدرة العقليـة العاليـة، والقدرة الإبداعيـة العاليـة، و التحصيل الأكاديمى المرتفع، والقدرة على القيام بمهار ات متميزة (فنيـة، رياضية، لغويـة، و القدرة على المثابرة والالتز ام، و الدافعية العالية، و المرونة، والاستقلالية فى التفكير" (شحاتة، وآخران,2003،76).

ـ الموهوبون لغويًا:

تعني المو هبة اللغويـة "قدرة معرفيـة محددة بحدود لغويـة, تسنو عب جميع اللغويات من نحو، وصرف، وأصـوات ولهجات، وقدرة أدبيـة محددة، تستو عب فروع الأدب شـررًا ونثرًا، ثم يلي ذلك قدرات خاصـة بالثـعر مسرحيًا، أو غنائيسا، أو قصصيًا, و أخرى خاصة بالنثر خطابًا, أو مقالًا أو رسالة أو قصة" (عصر، 2000، 69). ويعرف الموهويون لغويًا إجرائيا بأنهم: هم تلاميذ الصف الأول الإعدادي الذين يظهرون مستويات متقدمة من التطور اللغوى، والقدرة اللفظية والكتابية التى تتسم بالطلاقة و الوضوح، و عادة ما تكون حصيلتهم اللغوية متقدمة على أقر انهم العاديين، كما أنهم يتمتعون بمجموعـة من الخصـائص اللغويـة و المعرفية و الانفعالية التى تميز هم عن أقر انهم العاديين، ويمكن التعرُف عليهم من خلال أدوات الكثف المستخدمة في البحث الحالي. أهمية البحث:

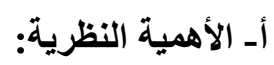
تقديم مادة عمية حول مهار ات التعبير الكتابي الإبداعي وأهميتها للتلاميذ، و التلاميذ المو هوبين لغويًا, وخصائصهم, و أسـاليب تنمية المو هبة لديهم. ب - الأهمية الميدانية: قد يفيد البحث كلًا من: 1 - تلاميذ الصف الأول الإعدادي الموهوبين لغويَّا: حيث قد يسهم البحث في تحديد مهارات التعبير الكتابي الإبداعي المناسبة لهم وتعرف مدى نو افر ها لديهم. 2 - معلمي اللفة العربية وموجهيها: من خلال توجيههم إلى ضرورة الاتهـام بتعليم التعبير الكتابي الإبـاعي وتتميـة مهار اته لدى 
3 - الخبراء ومخططي ومعدي برامج اللغة العربية: وذلك بتوجيه عنايتهم إلى أهمية مهار ات التعبير الكتابي الإبداعي في اللغة العربية، وأهية استخدام إستر اتيجيات تدريسية حديثة في تعليم هذه المهار ات.

4 - الباحثين: حيث يفتح البحث المجال أمامهم للقيام بدر اسات أخرى، ودراسـة مهارات التعبير الكتابي الإبداعي المناسبة لفئات أخرى من المتعلمين بالمر احل التعليمية المختلفة. هدفا البحث: هدف البحث الحالي إلى:

1 - تحديد مهار ات التعبير الكتابي الإبداعي المناسبة لتلاميذ الصف الأول الإعدادي الموهوبين لغويًّا. 2 - تعرف مدى تو افر مهار ات التعبير الكتابي الإبداعي لدى تلاميذ الصف الأول الإعدادي المو هوبين لغويًّا.

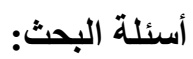

سعى البحث الحالي إلى الإجابة عن الأسئلة التالية:

1- ما خصائص تلاميذ الصف الأول الإعدادي المو هوبين لغويًا (المعرفيةـ الانفعاليةـ اللغوية)؟

2 - ما مهار ات التعبير الكتابي الإبداعي المناسبة لتلاميذ الصف الأول الإعدادي المو هوبين لغويَّا؟

3- ما مدى تو افر مهار ات التعبير الكتابي الإبداعي لاى تلاميذ الصف الأول الإعدادي الموهوبين لغويًا؟

محددات البحث:

اقتصر البحث الحالي على المحددات التالية:

المحدد المكاني: تم تطبيق هذا البحث في مدرسة الو عاضلة الإعدادية المشتركة، إدارة صدفا التعليمية بمحافظة أسيوط. المحدد الموضسوعي: بعض مهار ات التعبير الكتابي الإبداعي المناسبة للتناميذ الموهوبين بالصف الأول الإعداداي, عند مسـتوى: (الطلاقة, و المرونة, و الأصالة), بلغ عددها (14) مهارة. المحدد الزماني: طُبق البحث في الفصل الدراسي الثاني من العام الدر اسي 2019/2018. المحدد البشري: (37) تلميذًا وتلميذة من تلاميذ الصف الأول الإعدادي المو هوبين لغويَّا. منهجا البحث: في إطار التكامل المنهي عالج الباحثان مشكلة البحث باعتماد كل من المنهج الوصفي عند مر اجعة الأدبيات و الدر اسـات السـابقة و إعداد الإطار النظري للبحث، والمنهج التجريبي بالتصميم شبه التجريبي ذي المجموعة الواحدة عند تطبيق أدوات الدر اسة وموادها. مواد البحث وأدواته: مائمة خصائص التلاميذ المو هوبين لغويًّا (المعرفيةـ الانفعالبة ـ اللغوية). 


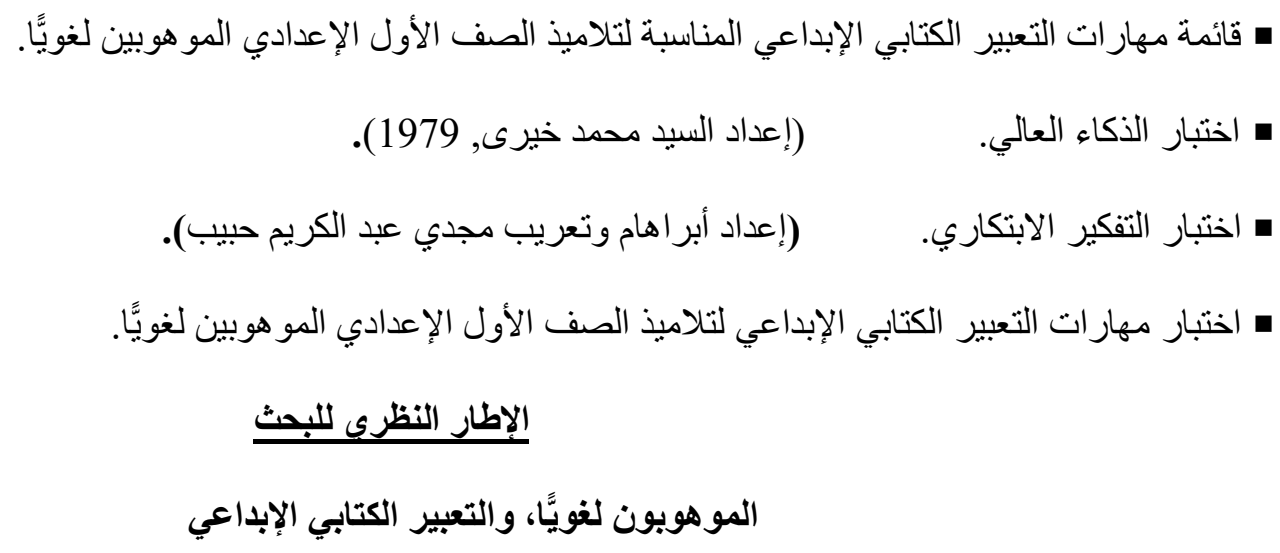

أولاً: الموهوبون لغويًًا:

لقد مر مفهوم المو هبة عبر العقود الماضية بمجموعة من التطور ات؛ فتحديد الطفل المو هوب بعتمد بشكل أساسي على اختبارت الذكاء التقليدية و التحصيل المدرسي، ومـع التطورات العلمية ونتيجـة أبحاث علمـاء آخرين فقد تم التأكيد على وجود عدد من العوامل الأخرى التي في ضوئها يتم تحديد المو هوب من بين أقرانه, كما تعددت تعريفات المو هوب لغويًا بين العلماء و التربويين, كما يلي: (1) تعريف الموهوب لغويًا:

يشير صـادق (2001, 2) إلى أن الموهوب هو الفرد الذي يتميز عن غيره بارتفاع مستوى الذكاء، بالإضـافة إلى زيادة العو امل الدافعية والمهارية لديه، وبتبي فكرة تعدد أنواع الذكاء، يمكن الوصول إلى فكرة تعدد المواهب أيضًا، مع الأخذ في الاعتبار أن الموهوب يحتاج إلى خدمات خاصة توصلـه إلى أكبر درجـة مـن استنمار إمكاناتهـ وقدراتـه. ويعرف المو هوب لغويَّا بأنه "المتعلم الذي يظهر مستوى مرتفعًا مـن الأداء اللغوي, واستعدادًا فريدًا في أحد المجالات اللغويـة، والتي تحتاج قدر ات خاصـة, شرط أن يكون هذا الفرد منمتعًا بمستوى مرتفع من الذكاء والابتكار" (مزيد، 2008، 15). كما يُعرف المو هوب لغويا بأنه التلميذ الذي يمتلك القدرة على الإنتاج اللغوي المتميز، ويظهر بر اعة في مجال الأداء اللغوي الإبداعي, ولديه من الاستعدادات و القدر ات اللغوية والابتكارية ما يؤهلـه لذللك، حيث بتمتع بمجموعة من الخصـائص اللغويـة والمعرفيـة والانفعالية التي تميزه عن غيره من الطلاب العاديين(محمد، 2014، 20). ويمكن تعريف المو هوب لغويًا بأنه التلميذ الذي يمنلك قدرات لغوية عاليـة, تمكنه من التفوق على أقرانهه في المجالات اللغويـة المختلفة، حيث لا تقتصر مو هبته على الذكاء أو التحصيل اللغوي فقط، لكنه يظهر أداءً يتميز به عن بقية أقرانه بالمرحلة العمرية نفسها.

هنالك مجمو عة من الخصائص (اللغوية, و الانفعالية, و الاجتماعية) التي تميز التلاميذ المو هوبين لغويًا كما ذكر ها كل من: Clark, (1992, 33؛ جر اون، 2002، 60؛ قاسم، 2005؛ 87؛ القريطي، 2005؛ الز هراني، 2008، 45) كالتالي: 


\section{أبرز الخصائص اللغوية للموهوب لغويًا:}

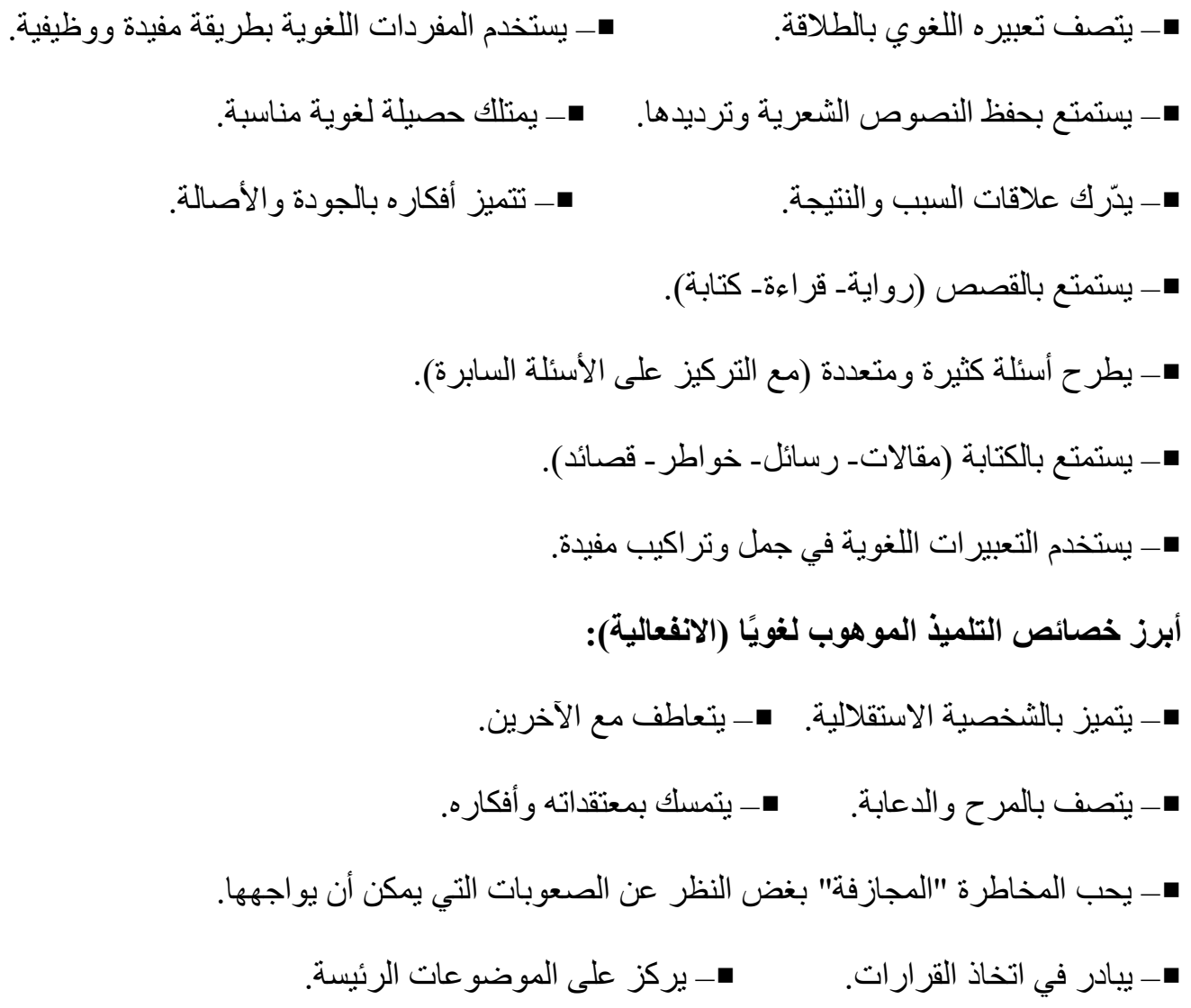

•- - يثابر في النشاطات التي يختار ها بنفسه.

أبرز خصائص الموهوب لغويًا (الاجتماعية):

•- يختاره الآخرون للمساعدة أو الانضمام إلى مجموعته.

•- - يحسن الاستماع و التو اصل مع الآخرين.

- - يستمتع بتكوين صداقات إيجابية جديدة.

ـ- يبادر في تقديم المساعدة العلمية لأقر انه.

•- يشتارك بحماس في النشاطات الجمعية.

•- يستطيع قيادة الآخرين عندما يتطلب الأمر ذلك.

ـ- يظهر إحساسا قويا بالعدالة الاجتماعية.

•- - ـشارك في تنظيم نشاطات التعلُّم مع أقر انه.

- - يعبر للآخرين عن مشاعره و أحساسيسه. 
فيتسم التلاميذ المو هوبون لغويًا بقدرتهم على التلاعب بالألفاظ شفهيًا وكتابيًا، وبحبهم للغة، ومتابعتهم الأنشطة اللغويـة داخل المدرسـة وخارجها، وحبهم القراءة وخاصة الكتب ذات المستوى الأعلى، وبقدرتهم على الكتابة ارتجالًا.

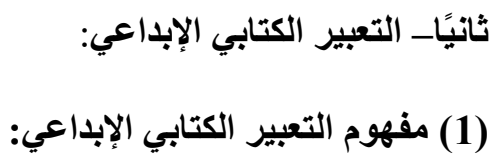

يعد التعبير الكتابي أحد أنواع فنون الكتابة الذي يشمل بالإضافة إليه كلًا من الخط والإملاء، ويعد التعبير الكتابي الإبداعي مطلبًا أساسيًا من مطالب التطور للإبداع و الأصالة و الطلاقة الفكرية لدى التلاميذ. ويعرف عطيـة (2007، 229) التعبير الكتابي الإبداعي بأنهـ ذلك النوع من التعبير, الذي يقصد بـه إظهار المشـاعر والعواطف الجياشة و الخيال المجنح, وذلك بعبار ات منتقاه بدقة تتسم بالجمال، والسلاسة والقدرة على الإثارة وإحداث الأثر في القارئ أو السـامع, أو إثارة الرغبة لديه في التعامل مع موضو عها. بينما يعرفه رشيد (2010، 20) بأنه إظهار المشاعر و الإفصاح عن العو اطف وخلجات النفس وترجمة الأحاسيس بعبارة منتقاة اللفظ، جيدة النسق، بليخة الصياغة، بما يتضمن صحتها لغويًا ونحويًا، وبحيث ينقل سامعها أو قارئها إلى المشاركة الوجدانية لمن قالها أو كتبها؛ كي يعيش معه في جوه وينفعل بانفعالاته، ويحس بما هو أحس باه. فيمتاز هذا النوع من التعبير بأنـه يستخدم الأسلوب الأدبي بإبداع؛ من حيث استخدامه للصسور البلاغية والكلمات، وعنايته بالشكل والمحتوى والمضمون، كما أنه لا بد أن يحتوي على عنصرين أساسيين, هما: الأصسالة الفنبة، والتعبير الثخصي أو الذاتي عن

$$
\text { (2) مهارات التعبير الكتابي الإبداعي: }
$$

من الضروري الاهتمام بتنمية مهار ات الإبداع لاى التلاميذ، وذلك حسب احتياجاتهم وقدر اتهم داخل الفصول، فمهار ات الإبداع مكتسبة وقابلة للنمو و الزيادة، ولعل من أهم مهار ات الإبداع اللغوي ما يلي:

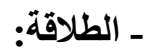

هنـاك تعريفـات متعددة للطلاقة، فتعـرف بأنها: القدرة على توليد عدد كبير من المتر ادفـات، أو الأفكار ، أو المشكلات، أو الاستعمالات عند الاستجابة لمثير معين، والسر عة و السهولة في توليدها. وهى في جو هر ها عملية تذكر و استلدعاء اختياريـة لمعلومـات أو خبرات أو مفاهيم سبق تعلمها(جروان، 2007، 220). وعرفها محمود (2007، 217) بأنها تعدد الأفكار الصحيحة لغويًا, التي يمكن أن يأتي بها الفرد وحده في فترة زمنية معينة. 
ويرى عبد الباري (2010، 158) بأنها عدد الأفكار التي يمكن أن يأتي بها المتعلم المبدع، وتتميز الأفكار المبدعة بملاءمتها لمقتضيات البيئة الو اقعيـة، وبالتالي يمكن أن تستبعد الأفكار العشوائية الصـادرة عن عدم معرفـة أو جهل كالخر افات، و عليه كلمـا كان المتعلم قادرًا على إنتاج عدد أكبر من الأفكار أو الإجابات في وحدة الزمن، توفرت فيه الطلاقة بشكل أكثر من أقرانه. يلحظ مما سبق من تعريفات للطلاقة أنها تتطلب الوفرة والتلاؤم، فالإنسان المبدع في اللغـة العربيـة هو الذي يمتلك ثروة من المفردات تتميز بالسهولة و السرعة و الدقة في الأداء, و الكثرة في إنتاج الاستجابات اللغوية المناسبة. وتتضمن الطلاقة الجانب الكمي في الإبداع، فتتضح الطلاقة في السهولة و السر عة التي يسنطيع بها المبدع استدعاء المعلومات من الذاكرة في وحدة زمنية معينة. وتتقسم الطلاقـة في اللغـة العربيـة إلى مكونـات فرعيـة أوردهـا عبد البـاري (2010، 159)، كمـا يلي: الطلاقـة الفكريـة, والطلاقة التز ابطية، والطلاقة التعبيرية، و الطلاقة اللفظية. وفي ضوء العرض السابق لمفهوم الطلاقة، وأنو اعها أو أبعادها يمكن تحديد مهار اتها الكتابية كما يلي:

1 وتعني القدرة على إنتاج عدد كبير من الأفكار في موقف معين (حبيب، 2000، 64). و عرفها فتح الباب (2016، 59) بأنها قدرة الفرد على أن ينتج عددًا كبيرًا من الأفكار في وقت محدد، وهذا يدل على أن هذا الفرد في حالة تو افر الظروف يمكن أن يصبح مثل: عباس العقاد، وتوفيق الحكيم وغيرهما، وتظهر تلك الطلاقة في التعبير الكتابي الإبداعي من خلال قدرة المتعلم على إنتاج أكبر عدد من الأفكار ذات الصلة الوثيقة بالمجال الإبداعي الذي يريد الكتابة فيه.

$$
\text { - ومن أهم المهارات التى تتعلق بها, ما يلي: (عبد الباري، 2010، 160) }
$$
- كتابة أكبر عدد ممكن من العناوين لموضوع محدد. ـ توليد أكبر قدر ممكن من الأفكار عن الموضوع في فترة زمنية محددة. ـ كتابة أكبر عدد من المقدمات المتعددة لنهاية واحدة. ـ كتابة أكبر عدد من العقد القصصية لقصة لها بداية ونهاية محددة.

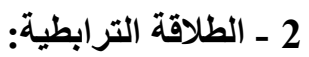

وتعني و عي الفرد بالعلاقات و السهولة التي يستطيع بها تقديم الفكرة بطريقة متكاملة المعنى (فتح الباب، 2016، 60).

$$
\text { - ومن مهار اتها ما يلي (عبد الباري، 2010، 159): }
$$

ـ كتابة أكبر عدد من الكلمات التي تدل على لفظ معين (المتر ادفات). ـ كتابة أكبر عدد من الكلمات التي تعبر عن أكثر من معنى (المشترك اللفظي). 


$$
\text { - 3- كتابة أكبر عدد من الكلمات التي تعبر عن عكس الكلمة (المتضادات). }
$$

وتعني قدرة المتعلم على ترجمة الأفكار التي قام بإنتاجها في أكبر عدد من الجمل و العبار ات، التي ترتب بطريقة وثيقة بـالمعنى

المر اد التعبير عنه، ولا يمكن أن يجيد المتعلم تللك القدرة إلا إذا توافر لديه مخزون لغوي واسع من كلمات و أثنعار وشو اهد بليغة، تجعله

يحسن استغلالها في التعبير عن المعنى الذي يتطلب التعبير عنه (حبيب، 2000، 64).

$$
\text { - ومن مهار اتها ما يلي: (عبد الباري، 2010، 159) }
$$$$
\text { - توليد أكبر عدد من الكلمات من مجموعة من الحروف. }
$$

ـ كتابة أكبر عدد من الجمل من كلمات قليلة.

$$
\text { ـ الربط بين الجمل؛ ليكون منها أكثر من موضوع. }
$$

ـ الكثتف عن الرو ابط المختلفة بين الجمل (علاقة سبب ونتيجة، عام وخاص، كل وجزء، تناقض).

4- الطلاقة اللفظية:

وتعني القدرة على كتابة أكبر عدد ممكن من الألفاظ، التي تتو افر فيها بعض الثروط البنائية الخاصـة كأن تحتوي على حرف

معين، أو تنتهي بحرف معين، و لا يعمل عامل المعنى دورًا مهمًا بها (فتح الباب، 2016، 60)

- ومن مهاراتها مـا يلي: (عبد الباري، 2010، 160)

ـ كتابة أكبر عدد من الكلمات التي تبدأ بحرف معين.

ـ كتابة أكبر عدد من الكلمات التي يتوسطها حرف معين.

ـ كتابة أكبر عدد من الكلمات التي تبدأ بمقطع معين، وتتنهي بالمقطع نفسه.

- إكمال الحروف الناقصة؛ ليولد منها كلمات ذات معني.

ـ اشتقاق أكبر عدد ممكن من الكلمات من كلمة أو فعل.

- مهارة الاشتقاق اللغوي.

ـ مهارة استكمال الأشكال اللغوية؛ لتعبر عن أكبر عدد ممكن من الجمل. 
وتعني قدرة المتعلم على توليد أفكار متنوعة ليست من نوع الأفكار المتوقعة، وتوجيه أو تحويل مسار التفكير مع تغير المثير، أو منطلبات الموقف، أي درجة السهولة التي يغير بها الثخص موقفًا ما، أو وجهة نظر معينة، و عدم التعصب لأفكار و أنماط ذهنية محددة سلفًا وغير قابلة للتغيير بحسب ما تستدعي الحاجة (أبو جبين، 2011، 68). ج- الأصالة: يُنظر إلى الأصسالة كما يرى أبو جادو ونوفل (2007، 163) أنها مرادفة للإبداع نفسـه، ويقصد بها تلك القدرة التي تبدو في سلوك الفرد عندما يبتكر بالفعل إنتاجًا جديدًا، فالأصالة بهذا المعنى تعني الجدة أو الندرة، بيد أن هناك شرطًا آخر لا بد من توافره إلى جانب الجدة كي يعتبر الإنتاج أصيلً، و هو أن يكون مناسبًا للهدف أو الوظيفة التي سيؤديها العمل المبتكر، وتعرف الأصسالة بأنها: القدرة على إبداء أو توليد أفكار جديدة، وفريدة، وخلاقة. فالأصـالة تختلف عن بقيـة القدرات الإبداعيـة، في كونهـا لا تشـير إلى كميـة استجابات المتعلم أو عددها بـل تهنم بجدة هذه الاستجابات، أي قلة تكر ارها بين الجماعة التي ينتمي لها. (3) أهداف تدريس التعبير الكتابي في المرحلة الإعدادية: لتتمية القدرة والمهارة على التعبير السليم الواضح الجميل لدى المتعلم، لا بد من تحقيق مجموعة من الأهداف الخاصـة، التي يجب أن يضعها المعلم نصب عينيه وهو يُدرس التعبير، ومن أهم تللك الأهداف ما ذكر عاشور ومقدادي (2005، 216) أن من الأهداف التي من أجلها يُدرس التعبير ما يلي: ـ تمكين التلاميذ من التعبير عن حاجاتهم ومشاعر هم ومشاهداتهم وخبر اتهم بعبارة سليمة صحيحة. ـ تزويد التلاميذ بما يحتاجونه من ألفاظ وتر اكيب؛ لإضافتها إلى حصيلتهم اللغوية، واستعمالها في حديثهم. ـ إكساب التلميذ مجموعة من القيم و المعارف و الأفكار و الاتجاهات السليمة.

ـ تعويد التلاميذ ترتيب الأفكار و التسلسل في طرحها و الربط فيما بينها، بما يضفي عليه جمالًَ وقوة ونأثثر في السامع و القارئ. ـ تهيئة التلاميذ لمواجهة المو اقف الحياتية المختلفة التي تتطلب فصاحة اللسان والقدرة على الارتجال؛ للعيش في المجتمع بفعالية. ـ تقوية لغة التلميذ وتنميتها وتمكينه من التعبير السليم عن خواطر نفسية شفهيًا وكتابيًا. ـ تنمية التفكير وتنشيطه وتنظيمه, و العمل على تغذية خيال التلميذ بعناصر النمو والابتكار. كما ذكر مدكور (2008، 257-258) أن أهداف تدريس التعبير تضمنت تنمية قدرة التلميذ على التعبير الإبداعي، وهذا يعني: 
ـ تنمية قدرة التلميذ على التعبير عن الأفكار و الأحاسيس والانفعالات والعو اطف ومشاعر الحزن و الفرح و الألم، ووصف مظـاهر الطبيعـة، و أحوال الناس، وكتابة الشعر ، والقصة، والمقالة، والمسرحية، وكل ما هو فكر جميل بأسلوب جميل.

ـ تدريب التلاميذ على استغلال المواد الأخرى في التعبير. فمدرس اللغة النابه، هو الذي يحيل تلاميذه إلى موضو عات في كتب الأدب و القر اءة و المو اد الاجتماعية؛ ففيها الكثير مما يمكن مناقتنه، أو التعليق عليه، أو تلخيصه، وفيها ما يعين التلميذ على الكتابة الإبداعية. كما حددت وثيقة اللفة العربية لمرحلة التعليم الأساسي (2011، 2012 ، 66-67) المؤشرات والمعايير الخاصة بالكتابـة والتي تمثلت فيما يلي:

$$
\begin{aligned}
& \text { - ينتج المتعلم الأفكار وينظم كتابتها. يكتب المتعلم مقدمة مشوقة. }
\end{aligned}
$$

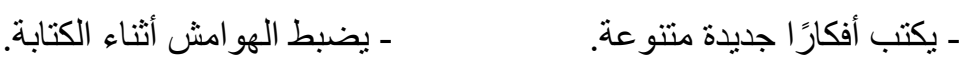

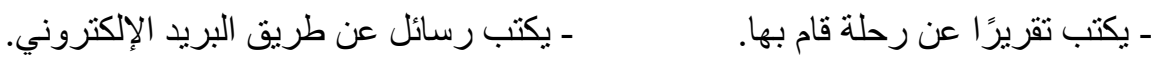

ومما سبق, يتضح أن إكساب مهارات التعبير الكتابي الإبداعي لتلاميذ الصف الأول الإعدادي المو هوبين لغويًا بشكل خاص أمر

في غاية الأهمية ومطلب تربوي يجب أن تسعى إليه المؤسسات التعليمية.

\section{إجراعات البحث}

(1) إعداد قائمة خصائص التلاميذ الموهوبين لغويًا (المعرفية_ الانفعاليةـ اللغوية) بالصف الأول الإعدادى.

\section{أـ تحديد الهدف من إعداد القائمة:}

تمثل الهدف من إعداد القائمة في تعرف الخصائص التي تميز التلاميذ الموهوبين لغويًا عن أقرانهم العاديين في المرحلة الإعدادية. مصادر إعداد القائمة:

تمثلت مصنادر إعداد القائمة في الدراسات والأدبيات السابقة التي تناولت خصـائص المو هوبين بصفة عامـة، والمو هوبين لغويًا بصـفة خاصـة، ومنهـا، دراسـة (2000) و أبـو عـوف (2004)؛ و القريطي (2005)؛ ومزيــ (2008)؛ والنجلاوي (2008)؛ وقطناني ومريزيق (2012), ومقابلة بعض المختصين في مجال منـاهج وطرق تدريس اللغنة العربيـة و علم النفس التربوي, وبعض معلمي اللغة العربية للإفادة منهم فيما يتعلق بخصائص هذه الفئة من المتعلمين. إعداد القائمة في صورتها الأولية:

وتضمنت القائمة في صورتها الأولية ثلاث خصائص رئيسة, هي: الخصائص المعرفيـة، والانفعالية، واللغويـة، اندرجت تحت كل منها مجمو عة من الخصائص الفرعية بلغ عددها (68) خاصية فرعية. 


\section{تحكيم القائمة:}

عُرضت القائمة في صورتها الأولية على المحكمين من المختصين في مناهج وطرق تدريس اللغة العربية، وعلم النفس التربوي، وبعض موجهي اللغة العربية ومعلميها؛ وذلك بهدف التوصل إلى شكلها النهائي، والأخذ بآرائهم فيما يتعلق بالتعديل و الحذف و الإضافة, بلغ عددهم (27) محكمًا. تعديل القائمة وفقا لنتائج التحكيم: بعد عرض القائمة على المحكمين تم حساب الأوزان النسبية لنسب اتفاقه على الخصائص الفرعية الواردة بالقائمة, كما يتضح بالجدول التالي.

\section{جدول(1):نسب اتفاق المحكمين على قائمة خصائص التلاميذ الموهوبين لغويًا في صورتها الأولية}

\begin{tabular}{|c|c|c|}
\hline 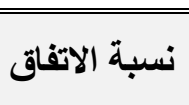 & الخصائص الفرعية & الخصائص العامة \\
\hline$\% 96.2$ & تنوع الاهتمامات العلمية. & \multirow{19}{*}{ الخصرفيائص } \\
\hline$\% 92.5$ & إدر آك العلاقات بين الأجزاء و الأفكار بصورة واضحة. & \\
\hline$\% 81.4$ & المرونة و السر عة في عمليات التفكير. & \\
\hline$\% 74.1$ & وفرة المعلومات في جميع المجالات العلمية. & \\
\hline$\% 77.7$ & تجنب الأحكام السريعة. & \\
\hline$\% 85.1$ & عمق الأفكار و أصالتها. & \\
\hline$\% 81.4$ & التوصل إلى حلول غير تقليدية للمشكلات. & \\
\hline$\% 74.1$ & قدرة عالية على التفكير المتشعب و التفكير التباعدي. & \\
\hline$\% 88.8$ & قوة التركيز والانتباه. & \\
\hline$\% 85.1$ & كثرة الاطلاع. & \\
\hline$\% 96.2$ & الفضول المعرفي. & \\
\hline$\% 92.5$ & تساؤلات تفوق مستوى عمره الزمني أو الصفي. & \\
\hline$\% 81.4$ & تفضيل العمل الاستقلالي. & \\
\hline$\% 77.7$ & قوة الذاكرة. & \\
\hline$\% 85.1$ & المثابرة. & \\
\hline$\% 81.4$ & كثرة البحث و إنشاء القو ائم والتصنيفات. & \\
\hline$\% 85.1$ & استيعاب ما يقدم إليه من مفاهيم ومعلومات بسر عة. & \\
\hline$\% 74.1$ & لديه اهتمامات بحثية ومعرفية متتو عة. & \\
\hline$\% 96.2$ & قدرات عالية في التفكير المجرد و التعامل مع الأنظمة الرمزية. & \\
\hline$\% 88.8$ & الإحساس بالاختلاف عن الآخرين. & \multirow{10}{*}{ الانفعالية } \\
\hline$\% 85.1$ & القدرة على الضبط الداخلي و التحكم بالذات. & \\
\hline$\% 96.2$ & توقع الأداء الأفضل من الذات. & \\
\hline$\% 92.5$ & السعي نحو الكمالية ومحاولة تحقيق الكمال. & \\
\hline$\% 81.4$ & حسّ الدعابة المرتفع. & \\
\hline$\% 74.1$ & حساسية عالية تجاه مشاعر الآخرين. & \\
\hline$\% 96.2$ & عمق العو اطف و الانفعالات وقوتها. & \\
\hline$\% 92.5$ & القيادية. & \\
\hline$\% 81.4$ & التمسكك بالقيم العليا كالعدالة و الحرية و المساو اة. & \\
\hline$\% 88.8$ & قوة الدافعية. & \\
\hline
\end{tabular}




\begin{tabular}{|c|c|c|}
\hline نسبة الاتفاق & الخصائص الفرعية & الخصائصة العامة \\
\hline$\% 85.1$ & السعي إلى تحقيق الذات. & \\
\hline$\% 96.2$ & الاهتمام بمشكلات الآخرين وتقديم المساعدة لهم. & \\
\hline$\% 77.7$ & قدرة جيدة على التمييز بين الصو اب و الخطأ و الحقوق و الو اجبات. & \\
\hline$\% 81.4$ & الحساسية المفرطة و الحدة الانفعالية. & \\
\hline$\% 88.8$ & الحماس في أداء المهمات و الاستغر اق الكلى فيها. & \\
\hline$\% 85.1$ & الشعور بالمسئولية والانضباط. & \\
\hline$\% 96.2$ & إصدار الأحكام على الذات والآخرين. & \\
\hline$\% 96.2$ & القدرة على التعبير الأصبل عن الأفكار. & \multirow{32}{*}{ الخصائص اللغوية } \\
\hline$\% 85.1$ & استخدام المصطلحات اللغوية بطريقة مفهومة ولها معنى. & \\
\hline$\% 81.4$ & اتسام الأفكار اللغوية بالجدة و التفرد. & \\
\hline$\% 96.2$ & اللمسات الإبداعية اللغوية في المنطوق أو المكتوب. & \\
\hline$\% 88.8$ & قدرة عالية على الربط بين الأشتات اللغوية لإنتاج أفكار جديدة. & \\
\hline$\% 85.1$ & التعامل مع الألغاز اللغوية بسهولة. & \\
\hline$\% 96.2$ & قدرة عالية على استخدام التر اكيب اللغوية المعقدة. & \\
\hline$\% 92.5$ & التعبير اللفظي المفصل لتفسير ما يدور حوله. & \\
\hline$\% 81.4$ & لديه حصيلة كبيرة من المفردات و المتر ادفات. & \\
\hline$\% 96.2$ & تكوين بناء معرفي لغوي يساعد في فهم العلاقات و المتر ابطات. & \\
\hline$\% 85.1$ & قدرة عالية على التفكير اللغوي المنظومي. & \\
\hline$\% 81.4$ & استيعاب المفردات اللغوية الجديدة. & \\
\hline$\% 85.1$ & إنتاج أساليب وصور لغوية جديدة. & \\
\hline$\% 96.2$ & استخدام ألفاظ لغوية غير متداولة في فئته العمرية. & \\
\hline$\% 74.1$ & معدل نمو لغوي ضخم. & \\
\hline$\% 88.8$ & قدرة على التوسع في المناقتشات و المحادثات و إثر ائها. & \\
\hline$\% 85.1$ & طلاقة لغوية وفكرية. & \\
\hline$\% 96.2$ & استيعاب المقروء بسهولة. & \\
\hline$\% 77.7$ & قر اءة الموضو عات التي تتطلب تفكيراً مجرداً. & \\
\hline$\% 81.4$ & خيال لغوى خصب يتصف بالنشاط. & \\
\hline$\% 92.5$ & التعبير الإبداعي المتميز. & \\
\hline$\% 96.2$ & تدعيم الأفكار اللّغوية بالأدلة والثو اهد. & \\
\hline$\% 77.7$ & استخدام الصور البيانية والمواقف البلاغية بشكل إبداعي. & \\
\hline$\% 96.2$ & أصالة الأفكار اللغوية المطروحة. & \\
\hline$\% 85.1$ & توليد معان لغوية متعددة لفكرة واحدة. & \\
\hline$\% 81.4$ & قدرة على ترتيب الأفكار اللغوية و اكتشاف الثغرات. & \\
\hline$\% 88.8$ & توظيف الألفاظ في سياقات لغوية ابتكارية. & \\
\hline$\% 74.1$ & قدرة لفظية وتطور لغوي مرتفع. & \\
\hline$\% 85.1$ & الميل للقز اءة الحرة. & \\
\hline$\% 96.2$ & الجر أة الأدبية و القدرة الخطابية و التمثيلية. & \\
\hline$\% 92.5$ & الإحساس بالجمال وتذوقه في النصوص الأدبية. & \\
\hline$\% 74.1$ & معالجة النظم اللغوية المجردة. & \\
\hline
\end{tabular}

وقد اتفق المحكمون على الخصائص العامة أو الرئيسة بالقائمة دون تعديل أو حذف، أمـا في الخصـائص الفرعية فقد تم حذف

بعض الخصائص التي لم تصل نسبة الاتفاق عليها إلى 80\%، وتعديل بعض الخصـائص، و الخصـاص الفرعيـة التي حذفت هي: وفرة المعلومات في جميع المجالات العلميةـ تجنب الأحكام السريعةـ قوة الذاكرة- قدرة عالية على التفكير المتشعب و التفكير التباعديـــــــــ 


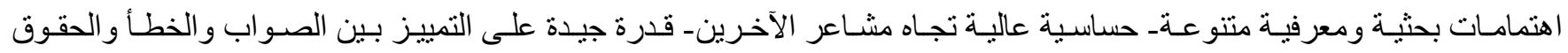
و الواجباتـ معدل نمو لغوي ضخمـ قر اءة الموضـوعات التي تتطلب تفكيراً مجرداً استخدام الصور البيانيـة والمواقف البلاغية بشكل إبداعي- قدرة لفظية وتطور لغوي مرتفع- معالجة النظم اللغوية المجردة, قد بلغت (12) خاصية. أما الخصائص التي تم تعديلها فهي: كثرة البحث و إنشاء القوائم والتصنيفات, وعُلت إلى "الاهتمامات البحثية و إنشاء القوائم و التصنيفات". و "السعي نحو الكمالية ومحاولة تحقيق الكمال", وعدلت إلى "السعي نحو الكمالية في كل الأعمال التي يؤديها", و"قدرة على ترتيب الأفكار اللغوية واكتشاف الثغرات, وتم تعديلها إلى "قدرة على ترتيب الأفكار وتسلسلها". قائمة خصائص التلاميذ الموهوبين لغويا في شكلها النهائي:

بعد تعديل قائمة خصائص الموهوبين لغويا من تلاميذ الصف الأول الإعدادي وفقا لآراء المحكمين أصبحت في شكلها النهائي تحتوي على ثلاث خصائص عامة هي: الخصائص المعرفية والخصائص الانفعالية والخصائص اللغوية، وقد اندرجت تحت كل منها مجموعـة من الخصائص الفرعية تضمنت (56) خاصية فرعية, و الجدول التالي يوضح الأوزان النسبية للقائمة في شكلها النهائي. جدول (2): الأوزان النسبية لخصائص التلاميذ الموهوبين لغويًا بالصف الأول الإعدادي في صورتها النهائية

\begin{tabular}{|c|c|c|}
\hline الوزن النسبي & عدد الخصائص الفرعية & الخصائص العامة \\
\hline$\% 25$ & 14 & الخصائص المعرفية \\
\hline$\% 26.8$ & 15 & الخصائص الانفعالية \\
\hline$\% 48.2$ & 27 & الخصائص اللغوية \\
\hline$\% 100$ & 56 & مجموع \\
\hline
\end{tabular}

وبالتوصل لقائمة خصائص تلاميذ الصف الأول الإعدادي الموهوبين لغويًا يكون قد تمت الإجابة عن السؤال الأول للبحث, ونصـه: "ما خصائص تلاميذ الصف الأول الإعدادي الموهوبين لغويًا (المعرفية ـ الانفعالية_ اللغوية)؟ (2) أدوات التعرُّف والكثف عن التلاميذ الموهوبين لغويًا بالمرحلة الإعدادية: أـ اختبار الأكاء العالي (إعداد السيا محمد خيري، 1979) هدف الاختبار: هدف اختبار السيد محمد خيري (1979) إلى قياس القدرة على الحكم والاستنتاج من خـلال ثلاثنة أنواع من المو اقف: مو اقف لفظية، ومو اقف عددية، ومواقف تتناول الأشكال المرسومة، و أستخدم الاختبار في البحث الحالي بهدف الكثف عن التلاميذ المو هوبين لغويًا بالمرحلة الإعدادية؛ وتم اختياره من بين اختبار ات الذكاء؛ لأنها يركز على الجزء اللفظي اللغوي بصورة واضحة، وبالتالي فهو يقيس الذكاء العالي، وفي الوقت نفسه يشير إلى القدرات اللغوية المرتفعة لدى المفحوصين. 
يتكون الاختبار من (42) سؤالاً، تتدرج في الصعوبة، وتتضمن عينات مختلفة من الوظائف الذهنية، أهمها: ـ القدرة على تركيز الانتباه، الذي يتمثل في تنفيذ عدد من التعليمات دفعة واحدة. ـ الاستعداد اللفظي، ويتمثل في التعامل بالألفاظ في أسئلة التعبير والمتر ادفات. ـ القدرة على إدر الك العلاقات بين الأشكال، ويتمثل في المقارنة بين عدد من الأشكال للكثف عن العلاقة بينها. ـ الاستدلال العددي، ويتمثل في حل سلاسل الأعداد و التفكير الحسابي. ـ الاستدلال اللفظي، ويتمثل في الأحكام المنطقية والمتناسبات اللفظية.

بعد إجر اء التجربـة الاستطلاعية تم تحديد الزمن المخصص لإجراء الاختبار هو (30) دقيقة، بعد توزيع كراسـات الاختبار و إلقاء التعليمات الخاصة به، وتوضيح كيفية الإجابة عنه. طريقة تصحيح الاختبار: يُعطى كل مفحوص درجة واحدة عن كل سؤال يجيب عنه إجابة صحيحة. صدق الاختبار: قام السيد محمد خيري (1979) بحساب صدق الاختبار بطريقتن: الأولى: حساب معامل الصدق على أساس استخر اج العلاقة بين الاختبار، و اختبار الذكاء التانوي (لإسماعيل القباني)، ووجد أنه يسـاوي (0.69)، والثانية: حسـاب معامل الارتباط بين منوسط تقدير ات المعلمين لذكاء الطالب، ودرجته على الاختبار، وبلغ (0.64)، و هي معاملات ارتباط دالة إحصائية تشير إلى صدق الاختبار. ونم في البحث الحالي حساب صدق الاختبار من خلال: الصدق المنطقي: تـم التأكد مـن الصدق المنطقي أو صدق المحتوى عند عرض الاختبـار على المحكمين (23) محكمـا, حيث اتفق المحكمون على صدق الاختبار، وذللك بصلاحيته لقياس ما وُضع لقياسه، وأنه صالح للتطبيق على فئة التلاميذ المستهدفة. ثبات الاختبار: استخدم مُعدّ الاختبار طريقتين لحساب الثبات، الأولى: إعادة التطبيق على عينـة مكونـة من (582) طالبًا، وكان معامل الثبات يساوي (0.85)، والثانية: التجزئة النصفية، وطُبق الاختبار على عينـة مكونـة من (800) طالب، وكان معامل الثبات (0.88)، و هي معاملات ثبات مرتفعة، ويمكن الوثوق بها. 
وتم حساب ثبات الاختبار في البحث الحالي باستخدام معادلة (ألفا كرونباك)، وتعتهد هذه الطريقة على تطبيق الاختبار مرة واحدة، حيث طُبق الاختبار على عينة قدر ها (25) تلميذًا وتلميذة، وقد بلغ معامل الثبات بهذه الطريقة (0.84)، وبذلك بتضح أن الاختبار يتمتع بمؤشر ات صدق وثبات جيدة، لذا يمكن استخدامه في البحث الحالي، و الوثوق في نتائجه. بـ اختبار التفكير الابتكاري (إعداد أبراهام وتعريب مجدي عبد الكريم حبيب، 1990) هدف الاختبار: أعد "أبر اهام Abraham" اختبار التفكير الابتكاري عام 1977م؛ للكثف عند درجة ابتكارية الأطفال والمر اهقين، وقد قام "مجدي عبد الكريم حبيب" (1990) بترجمة هذا الاختبار وتقنينه؛ ليكون صـالحًا للتطبيق في البيئة المصرية، ويتميز هذا الاختبار بسهولة تطبيقه، ويصلح للتطبيق في جميع مر احل التعليم، ابتداءً من مرحلة ما قبل المدرسـة إلى المرحلة الجامعية، وأستخدم الاختبار في البحث الحالي كإحدى أدوات الكثف عن التلاميذ الموهوبين لغويًا بالمرحلة الإعدادية. وصف الاختبار: يتكون الاختبار من جزأين: الجزء الأول: تسمية الأشياء: ويتكون من أربعة أجز اء فرعية, يتضمن كل جزء منها اسم فئة من الفئات، و على المفحوص أن يكتب أكبر عدد ممكن من أسماء الأشياء التي تقع في هذه الفئة، ويقيس هذا الاختبار الطلاقة الفكرية، و المرونـة التلقائية، والأصـالة، ويُجـاب عن كل جزء فرعي في (5) دقائق، ومن ثم فإن الزمن المسموح به لمجموع الأجزاء الفرعية (20) دقيقة. الجزء الثاني: الاستعمالات غير المعتادة:

يتكون هذا الجزء من أربعة أجزاء فرعية، ويُطلب من المفحوص في هذا الجزء أن يفكر في أكبر عدد ممكن من الاستعمالات غير المعتادة لبعض الأشياء المعروفة، ويجاب عن كل جزء فرعي في (5) دقائق، ومن ثم فإن الزمن المسموح بـه لمجموع الأجز اء الفر عية (20) دقيقة، وتؤكد تعليمات هذا الاختبار ضرورة أن يكون كل استعمال مختلفًا عن الآخر، ويقيس هذا الاختبار الطلاقة الفكريـة و المرونة التلقائية و الأصالة. الزمن الكلي للاختبار: الزمن المسموح به لجميع أجزاء الاختبار هو (40) دقيقة، يُحسب منها (20) دقيقة لكل جزء من جزئي الاختبار ، وتُحدد (5) دقائق لكل نقطة فرعية. تصحيح الاختبار: تصحح درجة الطلاقة الفكرية من خلال حصر أسماء كل الأشياء والاستعمالات التي يذكر ها المفحوص بعد حذف التكرارات أو الأسماء غير المناسبة أو الغامضة لفئات الأشياء والاستعمالات التي تتضمنها بنود الاختبار. 
وتحدد درجة المرونة التلقائية من خلال ما يكثف عنه الفرد من تحو لات أو انتقالات من فئة إلى أخرى من فئات الاستجابة، أو على أساس عدد مرات التغيير في زاوية التفكير خلال الإجابة. أما درجة الأصسالة فيُعبر عنها إحصائيا بالنسبة المئويـة لتكر ار الاستجابة؛ فالإجابـة التي تتضمن قوة ابتكاريـة أصيلة ومتفردة تأخذ (درجنين)، و الاستجابة التي تكون قريبة واضحة وتظهر بعض القوة الابتكاريـة تأخذ (درجـة واحدة)، والاستجابة التي لا تعبر عن أي نوع من أنواع الأصالة تعطى صفر ا. ويكثف اختبار التفكير الابتكاري عن الطلاقة والمرونة والأصالة في جزئيه: تسمية الأشياء، والاستعمالات غير المعتادة، وتُحسب درجـة التفكير الابتكاري في كل الاختبار من خلال حساب مجموع الدرجات على كل من الطلاقة، والمرونة، والأصالة. إلا أن هذا الاختبار يتأثر في تصحيحه بتقدير ات المصحح، ووجهة نظره في طلاقة الإجابات، ومرونتها، و أصسالتها، ومع ذلك فإنه يعطي مؤشرات قوية في الكثف عن المو هبة اللغوية، بحيث يصعب الاستغناء عنه.

صدق الاختبار: تحقق "أبر اهام" المؤلف الأصلي للاختبار من صدقه باستخدام الاتسـاق الداخلي لله عن طريق حسـاب معاملات الارتباط بين الدرجات على كل بند والدرجة الكلية للاختبار، وتر اوحت قيم الارتباطات بين (0.32) و(0.92). وقام مجدي عبد الكريم حبيب بحسـاب صدق الاختبار باستخدام الصدق التلازمي بين الاختبار وتقديرات المعلمين للتفكير الابتكاري لأفر اد العينة ذاتها, وكان معامل الارتباط (0.76)، ويثبر ذلك إلى درجة صدق جيدة للاختبار. وفي البحث الحالي تم حساب صدق الاختبار من خلال: الصدق المنطقي: نم التأكد من الصدق المنطقي أو صدق المحتوى عند عرض الاختبار على المحكمين، بلـغ عددهم (23) محكما؛ حيث اتفق المحكمون على صدق الاختبار, وذلك بصلاحيته لقياس ما وُضع لقياسه، وأنه صالح للتطبيق على فئة التلاميذ المستهدفة.

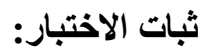
استخدم مؤلف الاختبـار الأصلـي (أبر اهـام) طريقـة التجزئـة النصفية لحسـاب ثبـات الاختبـار بالاستعانة بمعادلـة (سبيرمان بر اون)، وقد تراوحت قيم معاملات الثبات بين (0.64) و(0.90)، للطلاقة و المرونة والأصالة. أما مجدي عبد الكريم حبيب (1990)، فقد استخدم لحسـاب الثبات طريقة إعادة الاختبار وتراوحت قيم معاملات الثبات بين (0.61) و (0.79) للطلاقة و المرونة و الأصالة. 
وفي البحث الحالي تم حساب ثبات الاختبار باستخدام معادلة (ألفا كرونباك)، حيث طُبق الاختبار على عينـة قدر ها (25) تلميذًا وتلميذة بالصف الأول الإعدادي, وقد بلغ معامل الثبات بهذه الطريقة (0.81)، وبذلك يتضح أن الاختبار يتمتع بمؤشر ات صدق وثبات جيدة، لذا يمكن استخدامه في البحث الحالي.

\section{إعداد قائمة مهارات التعبير الكتابي الإبداعى المناسبة لتلاميذ الصف الأول الإعدادي الموهوبين لغويَّا.}

تطلب البحث إعداد قائمة بمهار ات التعبير الكتابي الإبداعي المناسبة لتلاميذ الصف الأول الإعدادي المو هوبين لغويَّا, وقد تم

$$
\text { إعدادها وفقًا للخطو ات التالية: }
$$

1 ـ تحديد الهدف من القائمة: و هو تعرف مهار ات التعبير الكتابي الإبداعي المناسبة لتلاميذ الصف الأول الإعدادي الموهوبين لغويَّا, و استخدامها في إعداد اختبار التعبير الكتابي الإبداعي.

$$
2 \text { - مصادر بناء القائمة: اعتمد الباحثان عند إعداد قائمة مهار ات التعبير الكتابي الإبداعي على: }
$$

الدر اسـات و البحوث السـابقة المرتبطـة بـالتعبير الكتابي الإبـداعي، ومـن هذه الدر اسـات دراسـة كل مـن: مدكور (2008)؛ عاصـي

$$
\text { (2012)؛ عبد الباري (2016)؛ شحاتة (2016)؛ مصلح (2017)، أحمد (2017). }
$$

أهداف تدريس التعبير في المرحلة الإعدادية، كما حددتها وزارة التربية والتعليح, وقد تم الإشارة إليها بالإطار النظري للبحث. مقابلة بعض المختصين في مجال المناهج وطرق تدريس اللغة العربية، وبعض المعلمين.

3 - إعداد القائمة في صورتها الأولية: نم حصر مجموعة من مهارات التعبير الكتابي الإبداعي المناسبة لتلاميذ الصف الأول الإعدادي المو هو بين لغويَّا وتصنيفها إلى ثلاث مهار ات رئيسـة, هي: الطلاقة، الأصـالة، المرونـة، وبلغت المهارات الفرعيـة من المحاور الثثلاث ثماني عشرة مهارة فرعية. 4- تحكيم القائمة: تمَّ عرض القائمـة في صورتها الأولية على(29) مُحَكمًا من المختصين في المنـاهج وطرق تدريس اللغـة العربيـة، و اللغذة العربيـة وآدابها؛ وذللك للأخذ بـآر ائهم فيمـا يتعلق بوضوح العبار ات علميـا، ولغويا، والتعديل، أو الحذف، أو الإضـافة، ومناسبة المهار ات لتلاميذ الصف الأول الإعدادي الموهوبين لغويَّا, وكانت نسب اتفاق المحكمين على القائمة كما يلي: 


\section{جدول(3) :نسب اتفاق المحكمين على مهارات التعبير الكتابي الإبداعي في الصورة الأولية للقائمة}

\begin{tabular}{|c|c|c|}
\hline 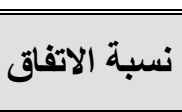 & المهارة الفرعية & الرئيسة \\
\hline$\% 89.6$ & كتابة أكبر عدد من الأفكار المرتبطة بالموضوع. & \multirow{8}{*}{ الطلاقة } \\
\hline$\% 100$ & يقتر ح أكبر عدد ممكن من النهايات لعمل أدبي: قصة،، خاطرة، مقال & \\
\hline$\% 82.7$ & يستخدم أكبر عدد من الأساليب الأدبية والبلاغية. & \\
\hline$\% 89.6$ & كتابة أكبر عدد ممكن من العناوين الرئيسية. & \\
\hline$\% 100$ & كتابة أكبر عدد ممكن من التعبير ات ذات المعنى عن موقف معين. & \\
\hline$\% 100$ & كتابة أكبر عدد ممكن من الجمل و العبار ات عن كل فكرة رئيسة. & \\
\hline$\% 68.9$ & اقتر اح مزيد من التفاصيل عن النص لإثراء الفكرة. & \\
\hline$\% 68.9$ & استخدام المفردات الجديدة وتوظيفها في الموضوع. & \\
\hline$\% 89.6$ & كتابة أسئلة متتو عة حول موضوع ما.. & \multirow{5}{*}{ 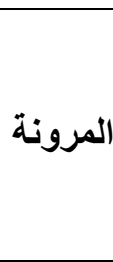 } \\
\hline$\% 86.2$ & كتابة مقدمات متنو عة تصلح لأن يبدأ بها أحد موضو عات التعبير. & \\
\hline$\% 89.6$ & كتابة أكبر عدد من الحلول المختلفة لمشكلة يعرضها في أثناء الكتابة. & \\
\hline$\% 100$ & إعادة كتابة النص بأسلوب أدبي آخر. & \\
\hline$\% 72.4$ & توظيف الشو اهد والاقتباسات & \\
\hline \%89.6 & تأليف قصة قصيرة معتمدًا على صورة مقدمة له & \multirow{5}{*}{ 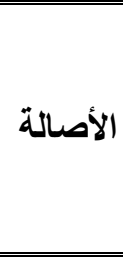 } \\
\hline$\% 100$ & كتابة نتائج مترتبة على حدث ما. & \\
\hline$\% 86.2$ & كتابة أفكارًا جديدة ومبتكرة حول موضوع معين. & \\
\hline$\% 86.2$ & توظيف معنى كلمة معينة في إنتاج أكبر عدد من الجمل. & \\
\hline$\% 72.4$ & رسم الصورة الفنية المعبرة. & \\
\hline
\end{tabular}

5 - ضبط قائمسة مهـارات التعبير الكتابي الإبـاعي: بعد عرض قائمـة مهارات التعبير الكتابي الإبداعي في صـورتها الأوليـة على المحكمين، تم تفريخ البيانـات التي تم جمعها وحسـاب الأوزان النسبية بين المحكمين لكل مهارة فرعية من المهار ات الرئيسـة؛ وذلك للاحتكام إلى هذه النسب في استبعاد بعض المهار ات التي حظيت بنسب اتفاق بين المحكمين أقل من 80\% و هو المعيار الذي اتخذه البحث كمعيار للإضافة والحذف.

وقد اتفق المحكمون على المهارات الرئيسة دون تعديل أو حذف، أمـا في المهار ات الفرعية فقد تم تعديل بعض المهارات، وحُذفت المهار ات التي لم تصل نسبة الاتفاق عليها إلى 80\%, و المهار ات الفر عية التي حذفت: اقتر اح مزيد من التفاصيل عن النص لإثراء الفكرة (الطلاقة)- استخدام المفردات الجديدة وتوظيفها في الموضوع (الطلاقة)- توظيف الثو اهد و الاقتباسـات (المرونـة)- رسم الصـورة الفنية المعبرة (الأصالة).

أما المهار ات الأدائية التي تم تعديلها في قائمـة مهار ات التعبير الكتابي الإبداعي فهي: "يقترح أكبر عدد ممكن من النهايات لعمل أدبي: قصة، خاطرة، مقال", وعدلت إلى "اقتر اح أكبر عدد ممكن من النهايات لعمل أدبي: قصـة، مقال، خاطرة", و"يستخدم أكبر عدد الأساليب الإنشائية و الخبرية, و عدلت إلى "التتويع بين الأساليب الأدبية و البلاغية" 
ومن ثم تم التوصل إلى الصورة النهائية لقائمة مهار ات التعبير الكتابي الإبداعي المناسبة لتلاميذ الصف الأول الإعدادي الموهوبين لغويَّا كما بالجدول التالي.

جدول(4): وصف قائمة مهارات التعبير الكتابي الإبداعي لتلاميذ الصف الأول الإعدادي الموهوبين لغويَّا في شكلها النهائي

\begin{tabular}{|c|c|c|}
\hline الوزن النسبي & عدد المهارات الفرعية & المهارات الرئيسة \\
\hline$\% 42.8$ & 6 & الطلاقة \\
\hline$\% 28.6$ & 4 & المرونة \\
\hline$\% 28.6$ & 4 & الأصالـة \\
\hline$\% 100$ & 14 & مجموع \\
\hline
\end{tabular}

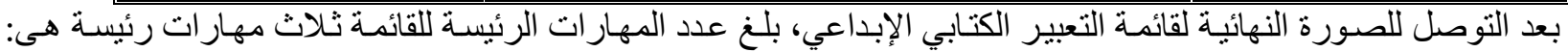

الطلاقة، والمرونة، والأصـالة، بينما بلـغ عدد المهار ات الفرعية أربع عشرة مهارة فرعيـة، وتتفق الدراسـة الحالية مع در اسـة كل من: محمد(2014)؛ أبو لبن(2016)؛ عبد الباري(2016)؛ أحمد(2017)؛ عبد العال(2018) في المهار ات الرئيسة وبعض المهارات الفرعية المندرجة تحتها.

وبذلك تمت الإجابة عن السؤال الثاني للبحث, ونصه: "ما مهارات التعبير الكتابي الإبداعي المناسبة لتلاميذ الصف الأول الإعدادي

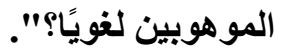

\section{(4) إعداد اختبار التعبيز الكتابى الإبداعى لتلاميذ الصف الأول الإعدادي الموهوبين لغويًا:}

تطلب البحث إعداد اختبار مهار ات التعبير الكتابي الإبداعي لقياس مستوى تلك المهار ات للى تلاميذ الصف الأول الإعدادي المو هوبين لغويًّا، وقد مر إعداد الاختبار بالخطوات التالية: أ ـ تحديد الهدف من الاختبار: تطلب البحث الحالي وضـع اختبار في مهار ات التعبير الكتابي الإبداعي لتلاميذ الصف الأول الإعدادي المو هوبين لغويًا، وقد هدف الاختبار إلى تعرف مدى تو افر مهارات التعبير الكتابي الإبداعي المحدة بالبحث لدى التنلاميذ. ب- مصادر بناء الاختبار: استند الباحثان إلى مجموعة من البحوث والدر اسات و التي تتصل بالإبداع لبنـاء الاختبـار منها، در اسـة موسى (2008)؛ محمد (2014)؛ ناصر (2017)؛ عبد العال (2018)؛ حسين (2018).

ج - وصف الاختبار: - - يقيس الاختبار ثناث مهار ات رئيسة من مهار ات التعبير الكتابي الإبداعي، وهى: (الطلاقةـ المرونة_ الأصالة). - تتضمن مهارة الطلاقة ست مهار ت فرعية، وتتضمن مهارة المرونة أربع مهار ات فرعية، وتتضمن مهارة الأصـالة أربع مهارات فرعية، وبذلك يكون إجمالي المهار ات الكلية أربع عشرة مهارة فرعية. - - اشتمل الاختبار على عشرين سؤالاً؛ حيث تقيس الأسئلة مهارات التعبير الكتابي الإبداعي. 
جدول(5): يوضح توزيع مهارات التعبير الكتابي الإبداعي في صورتها النهائية على أسئلة الاختبار

\begin{tabular}{|c|c|c|c|c|c|}
\hline \multirow[b]{2}{*}{ الأسئلة } & \multicolumn{3}{|c|}{ أرقام الأسئلة } & \multirow[b]{2}{*}{ 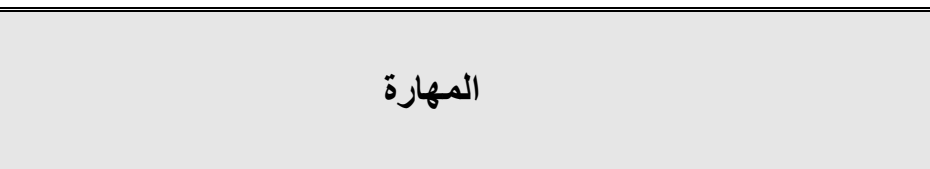 } & \multirow{2}{*}{ الرئيسة } \\
\hline & الثالثء & الثانيء & الأجزء & & \\
\hline \multirow{6}{*}{8} & & 8 & 6 & كتابة أكبر عدد من الأفكار المرتبطة بالموضوع. & \multirow{6}{*}{ الطلاقة } \\
\hline & - & - & 4 & اقتراح أكبر عدد ممكن من النهايات لعمل أدبي(قصة_-مقال- خاطرة). & \\
\hline & & 9 & & التنويع بين الأساليب الإنشائية و الخبرية & \\
\hline & - & - & 1 & يكتب أكبر عدد ممكن من العناوين الرئيسة. & \\
\hline & 15 & - & - & كتابة أكبر عدد ممكن من التعبيرات ذات المعنى عن موقف معين. & \\
\hline & 16 & - & 2 & كتابة أكبر عدد ممكن من الجمل و العبارات عن كل فكرة رئيسة. & \\
\hline \multirow{4}{*}{6} & - & 11 & 3 & كتابة مقدمات متنو عة تصلح لأن يبدأ بها أحد موضو عات التعبير . & \multirow{4}{*}{ 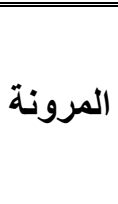 } \\
\hline & - & $12-10$ & - & كتابة أكبر عدد من الحلول المختلفة لمشكلة يعرضها أنثاء الكتابة. & \\
\hline & - & - & 5 & إعادة كتابة النص بأسلوب أدبي آخر & \\
\hline & 18 & - & - & كتابة أسئلة متتو عة حول موضوع ما. & \\
\hline \multirow{4}{*}{6} & & 13 & & تأليف قصة قصبرة معتمدًا على صورة مقدمة له & \multirow{4}{*}{ 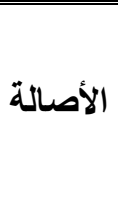 } \\
\hline & 17 & 14 & - & كتابة نتائج مترتبة على حدث ما. & \\
\hline & 19 & - & - & كتابة أفكارًا جديدة ومبتكرة حول موضو ع معين. & \\
\hline & 20 & - & 7 & توظيف معنى كلمة معينة في إنتاج أكبر عدد من الجمل. & \\
\hline
\end{tabular}

دـ التجربة الاستطلاعية للاختبار: بعد التوصل للصورة النهائية للاختبار تم تطييقه على عينة استطلاعية بلغ عددها(25) نلميذًا وتلميذة.

من تلاميذ الصف الأول الإعدادي المو هوبين لغويًا، بمدرسة الوعاضلة الإعدادية المشتركة التابعة لإدارة صدفا التعليمية؛ وذلك لتحديد ما

ـ صدق الاختبار: يقصد بصدق الاختبار كفاءته في قياس ما وضع لقياسه، وقد اعتمد الباحث في تحديد صدق الاختبار على نوعين من الصدق:

ـ صدق المحكين: حيث تم عرض الاختبار في صورته الأولية على مجموعة من المكمين المتخصصين في المناهج وطرق التدريس، بلغ عددهم 27 محكمًا. ـ صدق الاتساق الاخلي: حيث أمكن حساب معاملات الارتباط بين درجة الفقرات ودرجة الأبعاد الفر عية وكذلك حساب معامل الارتباط بين الأبعاد الفرعية والدرجة الكلية للاختبار. 
جدول(6): الاتساق الداخلي بين الفقرات والأبعاد الفرعية، ودرجة الأبعاد والارجة الكلية لاختبار التعبير الكتابي الإبداعي لاى عينة

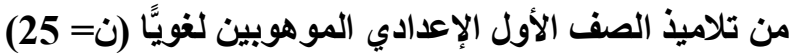

\begin{tabular}{|c|c|c|c|c|c|}
\hline \multicolumn{2}{|c|}{ الأصالة } & \multicolumn{2}{|c|}{ المرونة } & \multicolumn{2}{|c|}{ الطلاقة } \\
\hline الارتباط & الفقرة & الارتباط & الفقرة & الارتباط & الفقرة \\
\hline$* * 0.745$ & 7 & $* * 0.741$ & 3 & $* * 0.520$ & 1 \\
\hline$* * 0.658$ & 13 & $* * 0.654$ & 5 & $* * 0.754$ & 2 \\
\hline$* * 0.695$ & 14 & $* * 0.847$ & 10 & $* * 0.732$ & 4 \\
\hline$* * 0.739$ & 17 & $* * 0.812$ & 11 & $* * 0.841$ & 6 \\
\hline$* * 0.790$ & 19 & $* 0.760$ & 12 & $* * 0.621$ & 8 \\
\hline$* * 0.700$ & 20 & $* * 0.754$ & 18 & $* * 0.741$ & 9 \\
\hline & & & & $* * \mathbf{0 . 6 5 8}$ & 15 \\
\hline & & & & $* * 0.741$ & 16 \\
\hline \multicolumn{2}{|c|}{$* * 0.881$} & \multicolumn{2}{|c|}{$* * 0.841$} & \multicolumn{2}{|c|}{$* * 0.749$} \\
\hline
\end{tabular}

يتضح من خلال الجدول السابق أن معاملات الارتباط بين درجة الفقرات بالاختبار تعبر عن اتساق داخلي جيد للاختبار ؛ مما يدل على صلاحية الاختبار للتطبيق على عينة البحث. ـ حساب معامل ثبات الاختبار: تم حساب ثبات الاختبار بطريقتين، هما: أـ معامل ألفا كرونباخ: حيث تم حساب ثبات الاختبار باستخدام معامل ألفاكرونباخ؛ وذلك بتطبيقه على مجموعة من تلاميذ الصف الأول الإعدادي المو هوبين لغويًّا بلغ عددها (25) تلميذًا وتلميذة. جدول(7): معامل ثبات ألفا كرونباخ لاختبار التعبير الكتابي الإبداعي لتلاميذ الصف الأول الإعدادي الموهوبين لغويًّا

\begin{tabular}{|c|c|}
\hline معامل ألفا كرونباخ ن (25) & المتغيرات \\
\hline 0.738 & مهارات الطلاقة \\
\hline 0.831 & مهارات المرونة \\
\hline 0.741 & مهارات الأصالة \\
\hline 0.755 & الدرجة الكلية للتعبير الكتابي الإبداعي \\
\hline
\end{tabular}

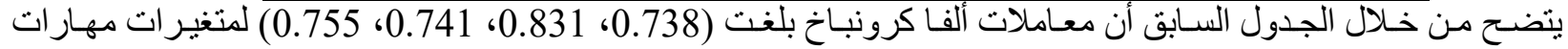

الطلاقة، و المرونـة، والأصـالة، والدرجة الكلية للتعبير الكتابي الإبداعي، وهي قيم تعبر عن مستوى ثبـات جيد للاختبـار ؛مـا يجعل الباحثين مطمئنين لاستخدام الاختبار بالبحث الحالي. ب- طريقة التجزئة النصفية: حيث تم حساب ثبات الاختبار باستخدام طريقة التجزئة النصفية؛ وذلك بتطبيقه على مجمو عة من تلاميذ الصف الأول الإعدادي المو هو بين لغويًا بلغ عددهم (25) تلميذًا وتلميذة. 
جدول (8): ثبات التجزئة النصفية لاختبار التعبير الكتابي الإبداعي لتلاميذ الصف الأول الإعدادي الموهوبين لغويًًا (ن= 25)

\begin{tabular}{|c|c|c|c|}
\hline \multicolumn{2}{|c|}{ ثُبات التجزئة بعد تصحيح أثر طول } & \multirow[t]{2}{*}{ معامل الارتباط } & \multirow[t]{2}{*}{ المتغيرات } \\
\hline جتمان & سبيرمان - براون & & \\
\hline 0.881 & 0.884 & 0.791 & مهارات الطلاقة \\
\hline 0.839 & 0.840 & 0.724 & مهارات المرونة \\
\hline 0.876 & 0.881 & 0.788 & مهارات الأصالة \\
\hline 0.729 & 0.745 & 0.594 & الدرجة الكلية للتعبير الكتابي الإبداعي \\
\hline
\end{tabular}

يتضـح مـن خـلال الجدول السـابق أن معـاملات ثبـات التجزئـة النصـفية بلغت (0.884، 0.840، 0.881، 0.745)، بمعادلـة

سبيرمان بر اون، وكمـا بلـغ ثبـات التجزئـة النصفية (0.881، 0.839، 0.876، 0.729)، بمعادلـة جتمـان لمتغير ات مهار ات الطلاقـة و المرونة و الأصالة والدرجة الكلية للتعبير الكتابي الإبداعي على التو الي, وهي قيم تعبر عن مسنتوى ثبات جيد للاختبار ؛ مما يدل على ثبات الاختبار وصلاحية للنطبيق بالبحث.

- حساب زمن الاختبار: تم تحديد زمن الاختبار عن طريق تحديد الزمن الذي استغرقه أول تلميذ في الإجابة عن مفردات الاختبار, حيث كان زمن خروج أول تلميذ 80 دقيقة، والزمن الذي استغرقه آخر تلميذ في الإجابـة عن مفردات, وكان زمن خروج آخر تلميذ 100 دقيقة، ثم قام الباحثان بقسمة مجموع الزمنين على عددهما لحساب المتوسط (الزمن التجريبي للاختبار)، وبالتالي أصبح منوسط زمن الاختبار 90 دقيقة. بالإضافة إلى 5 دقائق؛ لإلقاء تعليمات الاختبار، وبذلك أصبح الزمن الكلي للاختبار 95 دقيقة.

$$
\underline{100+80}=\quad \text { زمن الاختبار }
$$

2

ز - وضع نظام تقدير الارجات وطريقة التصحيح: تم الاعتماد في تحديد درجة كل مفردة على بطاقة تقدير متدرجة، كما بالجدول التالي: جدول(9): طريقة تصحيح اختبار التعبير الكتابي الإبداعي

\begin{tabular}{|c|c|c|c|}
\hline أداء غير مرض & أداء مقبول & أداء جيد & أداء ممتاز \\
\hline$\overline{11}$ & 2 & 3 & $\overline{44}$ \\
\hline
\end{tabular}

حيث تكونت بطاقة التقدير من أربعة خيارات: أداء ممتاز يحصل فيه التلميذ على أربع درجات، أداء جيد يحصل فيه التلميذ على ثلاث درجات، أداء مقبول يحصل فيه التلميذ على درجتين، أداء غير مرضٍ يحصل على درجة واحدة، وقد تم وضـع معايير لكل درجة من الدرجات لكل مفردة. 


\section{تجربة البحث}

بعد الانتهاء من إعداد أدوات البحث, و الحصول على الموافقات الإدارية اللازمة لتطبيق تجربة البحث, تم تطبيق البحث, وتمت التجربة كالتالي:

$$
\text { تحديد مجمو عة البحث. }
$$

تطبيق اختبار مهار ات التعبير الكتابي الإبداعي على مجموعة البحث.

ـ تحديد مجموعة البحث: تمثلت مجموعـة البحث في نلاميذ الصف الأول الإعدادي الموهوبين لغويَّا بمدرسـة الوعاضلة الإعداديـة المشتركة التابعة لإدارة صدفا التعليمية، حيث تم اختيار هـا من خـلال تطبيق اختبـار ات الكثف عن التلاميذ الموهوبين لغويـا المعتمدة بالبحث؛ حيث تم تطبيق اختباري الذكاء العالي و التفكير الابتكاري على جميع تلاميذ الصف الأول الإعدادي بالمدرسـة, البالغ عددهم (250) تلميذًا و تلميذة, وأسفرت النتائج عن أن (62) تلميذًا وتلميذة مو هوبون لغويًا, تم تقسيمهم إلى مجموعة استطلاعية قدر ها (25) تلميذًا, ومجموعة تجريبية أساسية للدر اسة بلغ عددها (37) تلميذًا وتلميذة. ـ تطبيق اختبار مهارات التعبيز الكتابي الإبداعي على التلاميذ:

تم تطبيق اختبار التعبير الكتابي الإبداعي على مجموعة البحث من نلاميذ الصف الأول الإعدادي الموهوبين لغويًا يوم الأحد المو افق 10/ 2/ 2019م؛ وذللك للوقوف على مستوى تلاميذ مجموعة البحث في مهار ات التعبير الكتابي الإبداعي، وتم التوصل إلى نتائج البحث من خلال تفريغ البيانـات ومعالجتها إحصـائيا، حيث تم إجر اء المعالجة الإحصـائية عن طريق الحاسب الآلي باستخدام البرنامج الإحصائي SSSS (الحزمة الإحصائية للعلوم الاجتماعية Statistical Package for Social Sciences).

\section{نتائج البحث وتفسيرها}

للإجابة عن السؤال الثالث من أسئلة البحث, والذي نصه: "ما مدى توافر مهارات التعبير الكتابي الإبداعي لاى تلاميذ الصف الأول الإعدادي الموهوبين لغويًَ؟ب

نم التوصل إلى الصورة النهائية لاختبار مهارات التعبير الكتابي الإبداعي، ثم اختيار مجموعة البحث، وتطبيق الاختبار، ومعالجة البيانات إحصائياً من خلال حساب المتوسط الحسابي والانحر اف المعياري لدرجات أفر اد مجموعة البحث في الاختبار , حيث (ن = 37). ويوضح الجدول التالي المتوسط الحسابي و الانحر اف المعياري وقيمة "ت" ودلالتها الإحصائية لدرجات أفر اد مجموعـة البحث في اختبار مهار ات التعبير الكتابي الإبداعي ككل ومهار اته الفرعية لدى تلاميذ الصف الأول الإعدادي المو هوبين لغويَّا. 
جدول(10): المتوسط الحسابي والاتحراف المعياري وقيمة "ت" ودلالتها لارجات مجموعة البحث في اختبار التعبير الكتابي (37

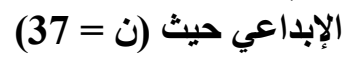

يتضح من الجدول السابق أن المتوسط الحسابي لدرجات تلاميذ مجموعة البحث على اختبار التعبير الكتابي الإبداعي ككل (49.86) و الانحر اف المعياري (2.74), و الدرجة الكلية للاختبار (80), حيث (ن= 37), أما عن المهارات الرئيسة التي تكون منها الاختبار, فكانت كالتالي:

* بالنسبة لمهارات الطلاقة: بلغ متوسط درجات التلاميذ مجموعة البحث على اختبار التعبير الكتابي الإبداعي في هذه المهارات (19.59), وبلغ الانحر اف المعياري (2.7), في حين أن الدرجة الكلية للمهارة (32) درجة. * بالنسبة لمهارات المرونة: بلغ منوسط درجات التلاميذ مجموعة البحث على اختبار التعبير الكتابي الإبداعي في هذه المهارات (15.19), وبلغ الانحر اف المعياري (1.52), في حين أن الدرجة الكلية للمهارة (24) درجة. * بالنسبة لمهارات الأصالة: بلغ منوسط درجات التلاميذ مجموعة البحث على اختبار التعبير الكتابي الإبداعي في هذه المهارات (15.08), وبلغ الانحر اف المعياري (1.01), في حين أن الدرجة الكلية للمهارة (24) درجة. وتشير النتائج السـابقة إلى ضـف مستوى التلاميذ الموهوبين لغويًا بالصف الأول الإعدادي في مهار ات التعبير الكتابي الإبداعي المستهدفة بالبحث؛ وقد يرجع ذللك إلى: - ضعف الاهتمام من قِبل المؤسسات التعليمية و المعلمين بتعرف التلاميذ المو هوبين لغويًا والكثف عنهم, ومن ثم تقديم الرعاية المناسبة لهم, وتحديد نقاط القوة لديهم لصقلها, ونقاط الضعف للعمل على علاجها. - استخدام طر ائق و إستر اتيجيات تدريس معتادة وتقليدية في تدريس اللغـة العربيـة لجميع التلاميذ ومن بينهم التلاميذ المو هوبين لغويًا, دون مر اعاة لخصائصهم المعرفية والتعليمية واللغوية التي يتميزون بها عن أقر انهم بالصف نفسه. - - الاهتمـام بالمستويات الدنيا من مهار ات التعبير عامـة والتعبير الكتابي خاصـة دون المستويات العليـا والإبداعية من تلك المهارات, و التي تتناسب وقدرات التلاميذ الموهوبين لغويًا في المرحلة الإعدادية.

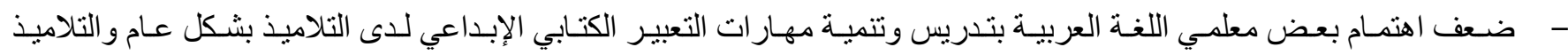
المو هوبين لغويًا بشكل خـاص, و التركيز بشكل رئيس على تدريس بقيـة فروع اللغـة الأخرى من موضـوعات قراءة, ونصوص, 


$$
\text { وقصة, وقو اعد نحوية. }
$$

- النمطية في الموضو عات التعبيرية المختارة للتلاميذ للكتابة فيها, وبُعدها عن ميول التنلاميذ و اهتماماتهر, وكذا في طريقة تصحيحها

$$
\text { التي تستند بشكل رئيس إلى المهار ات التنظيمية والثكلية للموضوع, مع ضعف الاهتمام بالمضمون. }
$$

وتتسق هذه النتائج مع نتائج عدة در اسات سـابقة أثـارت إلى ضـف المتعلمين عامـةً والمو هوبين لغويًا بشكل خاص في مهارات

التعبير الكتابي الإبـداعي, ومـن هذه الدراسـات, دراسـة كل من: محمود (2007), ومحمد (2014), وموسى (2008), و أبو لبن

(2016), و عبـدالباري (2016), وفتح البـاب (2016), و أحمد (2017), وحسـين (2018), وسـيد (2018), و عبدالعال (2018),

ومحمد (2020). 


\section{التوصيات و المقترحات}

توصيات البحث:

\section{في ضوء ما تم التوصل إليه من نتائج بالبحث, يوصى البحث بالآتي:}

ـ إجر اء المزيد من الدر اسات التي تهنم بالتعبير الكتابي، وتنمية مهار اته، وكذللك تضمين الكثف عن الأخطاء اللغويـة في التعبير الكتابي الإبداعي.

ـ توظيف الإستر اتيجيات الحديثة في تدريس التعبير، ورفع كفاءة المعلمين من خلال عقد دورات تدريية دورية لهم حول كيفية استخدام هذه الإستر اتيجيات. ـ الاهتمام بمجالات التعبير الكتابي الإبداعي والتي تهم التلاميذ وتتصل بحياتهم، وتقديمها لهم. ـ تضمين كتب اللغة العربية بعض موضو عات التعبير الكتابي. - إعطاء حصة التعبير الاهتمام الكافي من قبل وزارة التربية والتعليم، وبيان أهمية التعبير في حياتهم. ـ ترك الحرية للتنلاميذ لاختيار الموضوعات التي تتناسب مع ميولهم ورغباتهم تحت إثر اف معلميهم، وتقديم التوجيه إذا تطلب الأمر. ـ عقد دورات خاصة للمعلمين لتعريفهم بالإستر اتيجيات و الأساليب الحديثة لتدريس التعبير. ـ تشجيع التلاميذ على الكتابة الثخصية التي يعبرون من خلالها عن آرائهم، وخبر اتهم، ومشاعر هم. مقترحات البحث:

ـ مدى تو افر مهار ات الإبداع اللغوي لدى الطلاب المو هو بين لغويًا بالمرحلة الثانوية. - - برنامج مقترح لتنمية مهار ات التعبير الإبداعي لدى التلاميذ المو هوبين لغويًا بالمرحلة الإعدادية. ـ تقويم مقرر اللغة العربية لتلاميذ الصف الأول الإعدادي في ضوء مهارات الإبداع اللغوي المناسبة لهم. - برنامج مفترح قائم على بعض الأنشطة الإثر ائية لتنمية مهار ات التعبير الإبداعي لاى التناميذ المو هوبين لغويًا بالمرحلة الابتدائية. ـ دراسة مقارنة لأثر استخدام أكثر من إستراتيجية تعليمية في تنمية مهار ات التعبير الكتابي الإبداعي لدى الطلاب. 
- أبو جادو، صالح؛ نوفل، محمد بكر(2007). تعليم التفكير النظرية والتطبيق، الأردن، دار المسيرة.

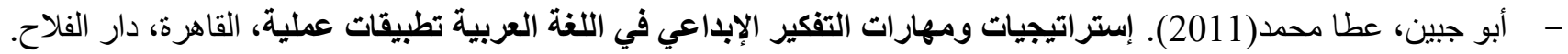

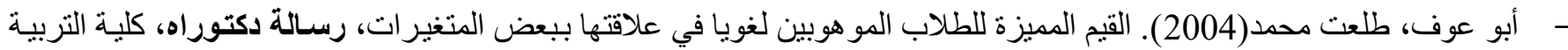

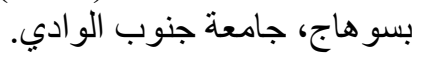

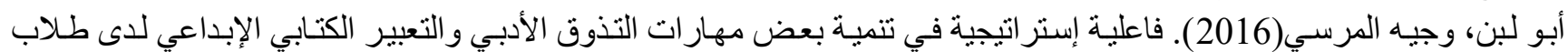
الصف الأول الثانوي، دراسات عربية في التربية وعلم النفس، رابطة التربويين العرب، السعودية التية، التئ، (71): 251-295.

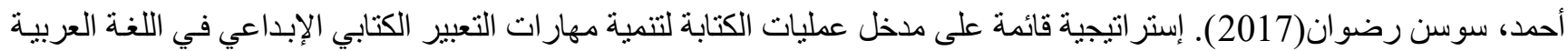

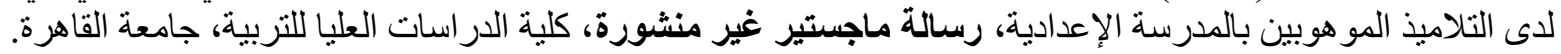

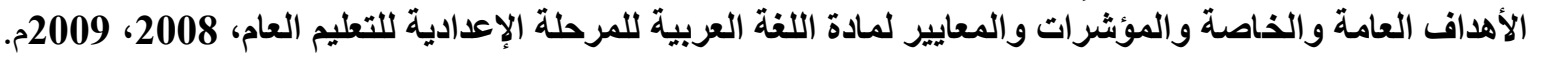

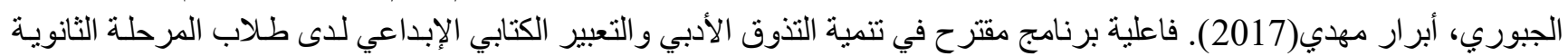

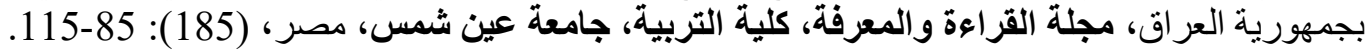

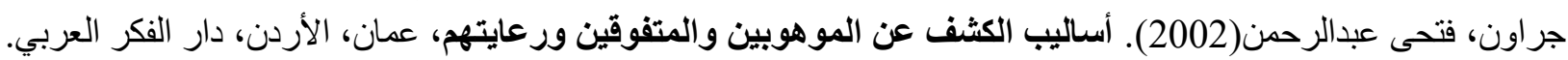

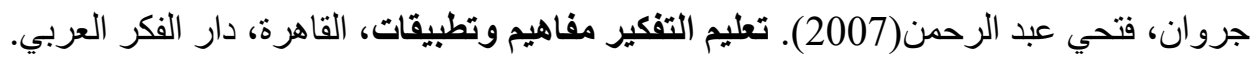

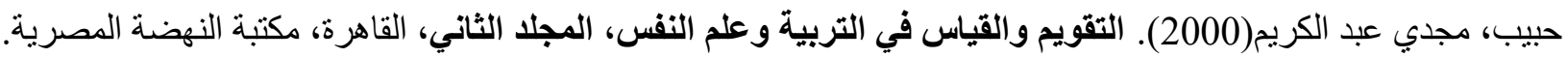

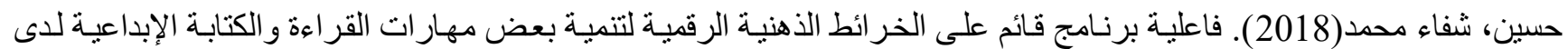

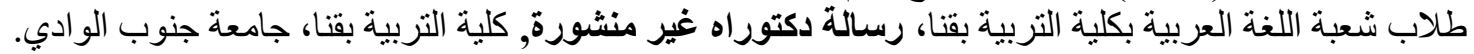

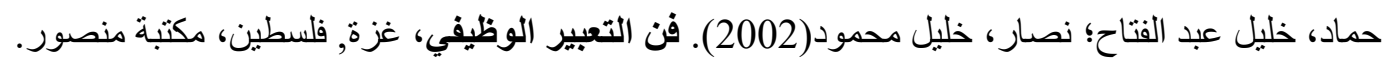

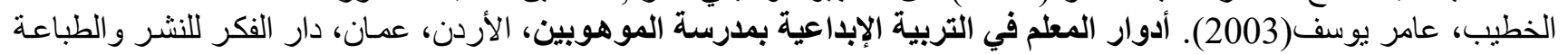
والتوزيع.

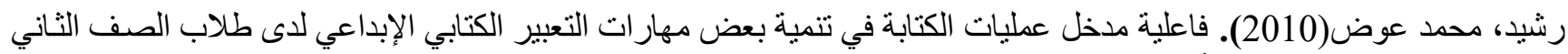
منو سط بالمدينة المنورة، رسالة ماجستير غير منشورة، كلية التربية، جامعة طيبة، السية السعودية.

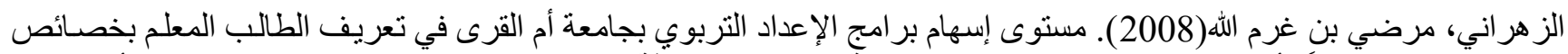

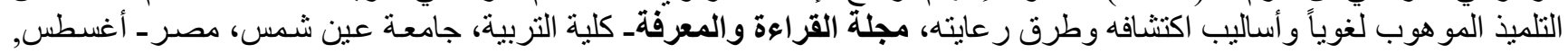
92-14: (81)

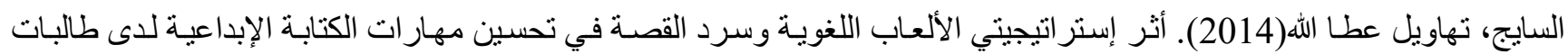

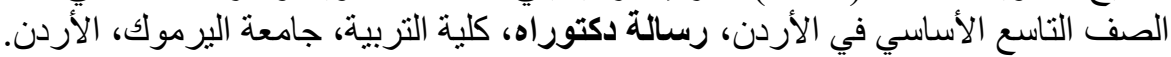

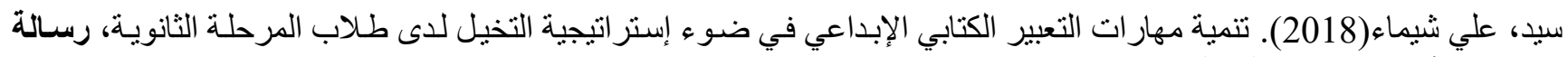
ماجستير غير منشورة، كلية التربية، جامعة عيدة عين شمس.

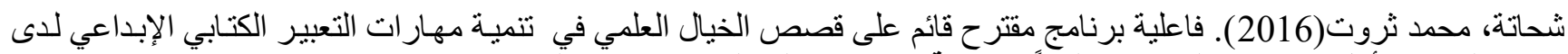

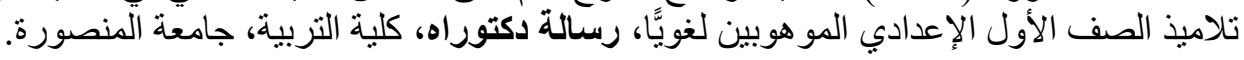
شحاتة, حسن؛ النجار, زينب؛ عمار , حامد (2003). معجم المصطلحات التربوية والنفسية، القاهرة، الدار المصرية التهبة اللبنانية.

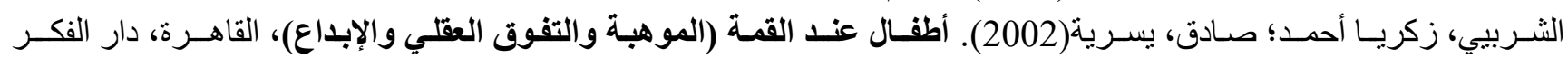
العـربي.

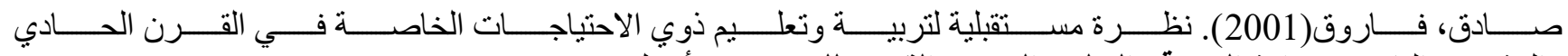

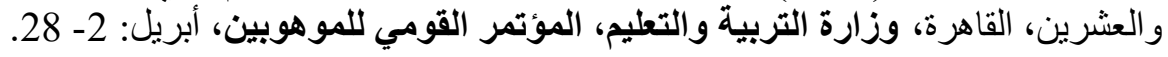

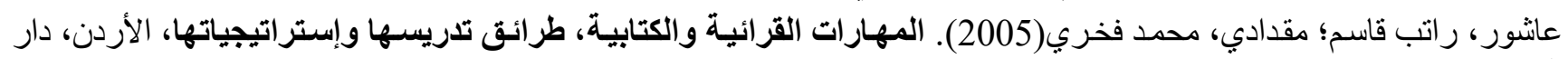
المسيرة.

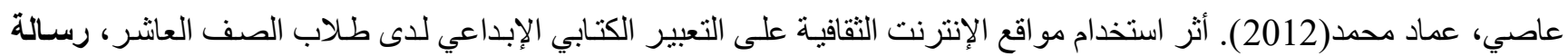
ماجستير غير منشورة، كلية التربية، الجامعة الإسلامية بغزة الإنترن، فلسطين. عباس، سعاد عبد الكريم(2004). طرائق تدريس الأدب والبلاغة والتعبير بين التظير والتطبة، التبيق، الأردن، دار الثروق.

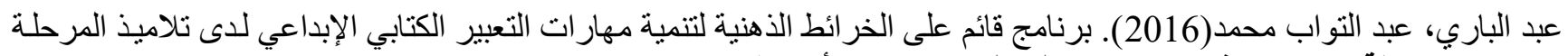
الإعدادية، رسالة ماجستير غير منشورة، كلية التربية، جامعة أسيوط. 


\section{عبد الباري، ماهر شعبان(2010). الكتابة الوظيفية والإبداعية، الأردن، دار المسيرة.}

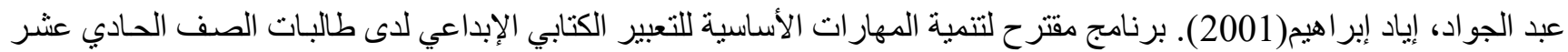
بمحافظة غزة، رسالة ماجستير ، كلية التربية، جامعة التئة عين شمس.

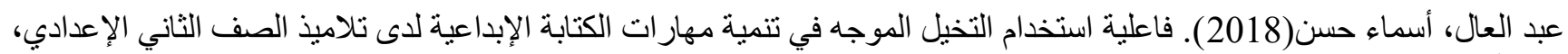
رسالة ماجستير غير منشورة، كلية التربية، جامعة المنيا.

$$
\text { 225- } 194 \text { - } 194 \text { (73) }
$$

عصر، محمد طه(2000)، جيكولوجية الموهبة الأدبية والطفولة، القاهرة، عالم الكتب.

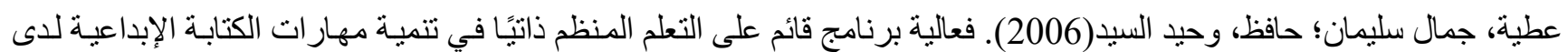

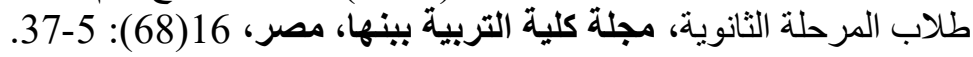

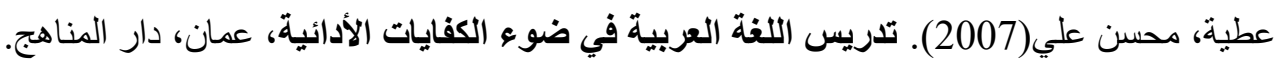

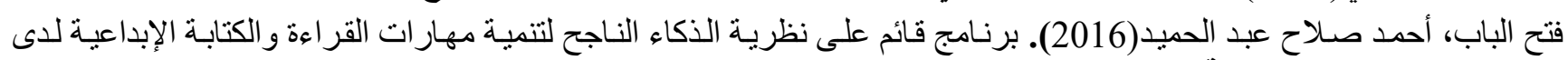

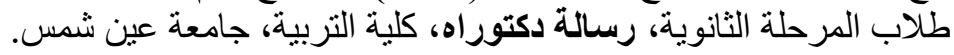

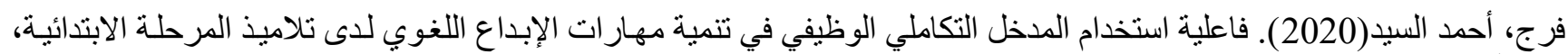
رسالة ماجستير، كلية التربية، جامعة المنصورة.

قاسم، محمد جابر (2005). معايير التفوق اللغوى للمعلم والمتعلم, الإمارات العربية المتحدة، دبى، دالئ، دار القلم. القريطي، عبد المطلب أمين(2005). الموهوبون والمتفوقون خصائصهم واكتثافهم ورعايتهم، القاهرة، دار الفكر العربي.

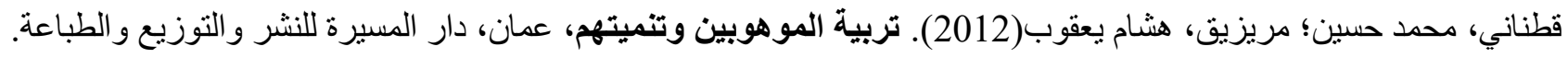

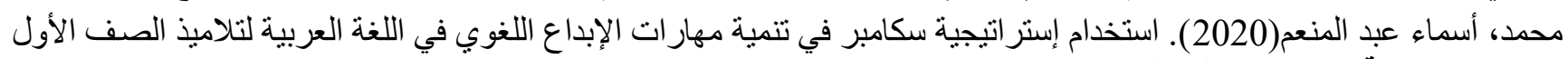
الإعدادي، رسالة ماجستير، كلية التربية، جامعة التهية دمياط.

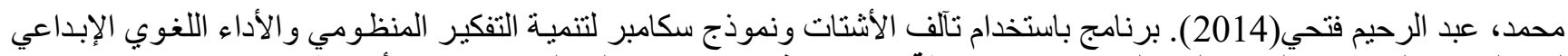

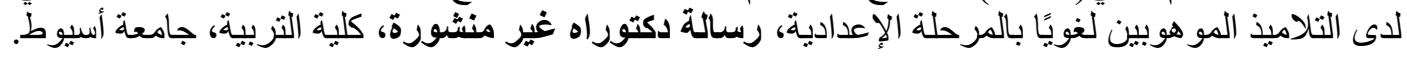

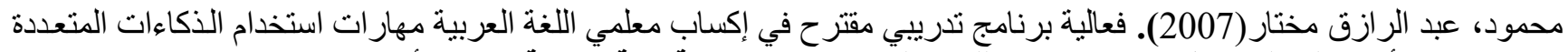

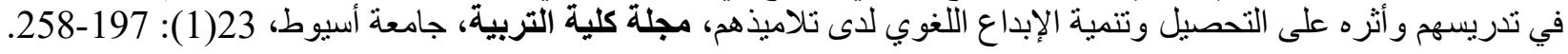

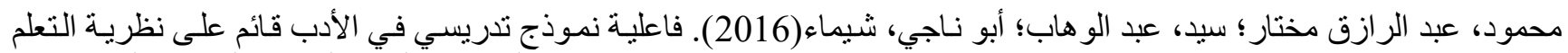

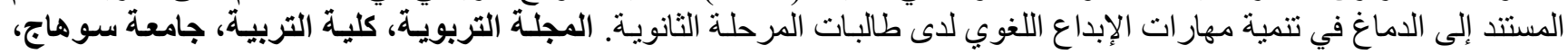

334-275:44

مدكور، علي أحمد(2008).

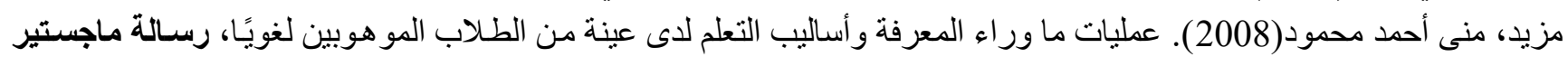
غير منشورة، كلية التربية، جامعة بنها.

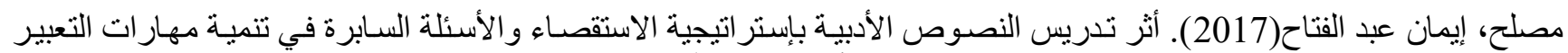

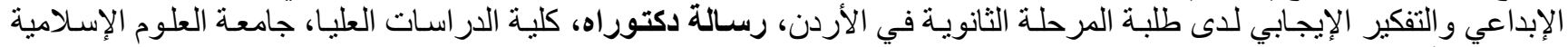
العالمية، الأردن.

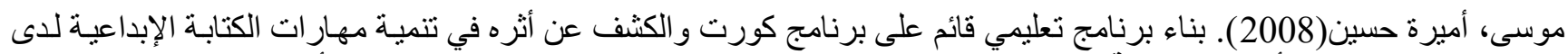

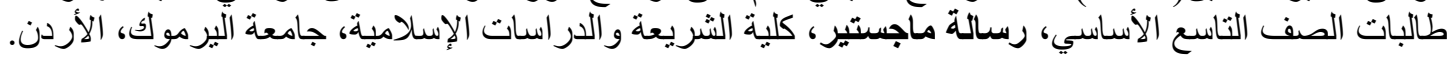

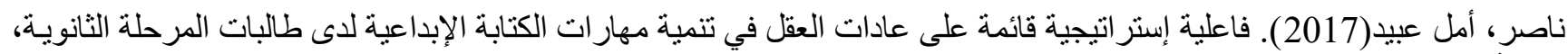
رسالة ماجستير، كلية التربية، جامعة الطائف، السعودية.

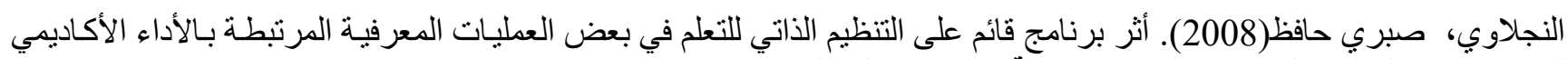

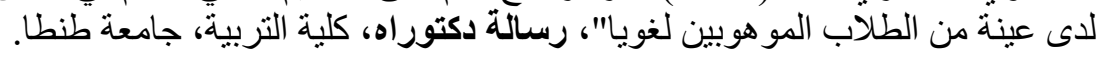

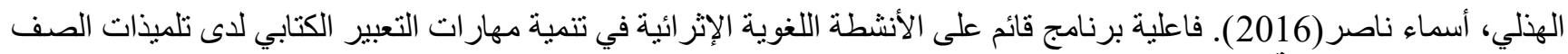

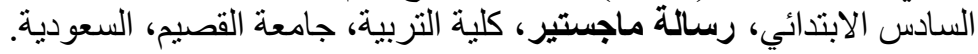

وثيقة اللغة العربية لمرحلة التعليم الأساسي، رسئل

- Swerling ,S .1 (2006): The use of Context Cues in Reading, Available: http://www.ldonline.org/spearswerling/ The_Use_of_Context_Cues_in_Reading. 
- Clark, B. (1992). Growing up giftedness. New York Macmillan Publishing company.

- Sarouphim, K. (2000). Internal Structure of DISCOVER A Performance Based Assessment. Journal for The Education of the Gifted, 23(3). 